\title{
Financial Frictions, the Great Trade Collapse and International Trade over the Business Cycle
}

\author{
Anna Watson ${ }^{1}$ (it) \\ Published online: 6 November 2018 \\ (C) The Author(s) 2018
}

\begin{abstract}
This paper investigates the impact of financial frictions on the dynamics of international trade over the business cycle and their role in the great trade collapse of 2008-2009. The study introduces cash flow constraints into an open-economy general equilibrium model with heterogeneous firms in which international trade is more dependent on external finance than domestic sales. The analysis demonstrates that endogenously driven countercyclical changes in the external finance premium amplify the effects of real and financial shocks on trade and help to explain the high trade income elasticity observed in the data. The paper shows that trade finance significantly contributed to the decline in trade during the global financial crisis. The model developed is also able to account for the sharp deterioration in the labour wedge and for the changes in the relative prices of domestic and exported goods during the crisis.
\end{abstract}

Keywords International trade - Financial frictions · Trade income elasticity · International business cycles $\cdot$ Great trade collapse

JEL Classification E44 $\cdot$ F41 $\cdot$ F44

\section{Introduction}

It is a well documented fact that international trade is procyclical and much more volatile than output (Engel and Wang 2011). For most countries and for the world as a whole, the estimates of the elasticity of real trade volumes with respect to real GDP are substantially higher than one (Irwin 2002; Kwack et al. 2007; Freund 2009). During the global financial crisis of 2008-2009 the decline in world imports and

Anna Watson

ac531@cam.ac.uk

1 Faculty of Economics and Fitzwilliam College, University of Cambridge, Storey's Way,

Cambridge CB3 0DG, UK 
exports was exceptionally large and nearly four times greater than the decrease in global GDP. Standard international business cycle models are unable to account for the severe fall in trade during the crisis and for the highly procyclical trade to GDP ratio. This paper investigates the impact of financial frictions on the dynamics of international trade over the business cycle and their role in the great trade collapse of 2008-2009.

A number of explanations have been put forward to account for the dramatic decline in world trade during the global financial crisis and the high trade income elasticity in general. They focus on vertical production linkages (e.g. Bems et al. 2010), compositional effects (Erceg et al. 2008; Levchenko et al. 2010; Engel and Wang 2011; Bussière et al. 2013; Eaton et al. 2016) and inventory adjustment (Alessandria et al. 2010). These factors have been shown to exert a strong effect on cyclical fluctuations in international trade and to have played a major role in the decline of world trade during the crisis. Nevertheless, they still leave a large part of the great trade collapse and the trade income elasticity unexplained. A number of empirical studies based on aggregate data (Chor and Manova 2012) and firmlevel statistics (Bricongne et al. 2012; Paravisini et al. 2015) have suggested that the substantial increase in the cost of trade finance observed during the financial crisis contributed to the decline in trade during that time. Financial shocks have been shown to have an adverse impact on trade also in other periods of financial turbulence (Iacovone and Zavacka 2009; Amiti and Weinstein 2011). Berman et al. (2013) show that the impact of financial crises on international trade is greater when shipping times between the exporter and importer countries are longer. This also suggests that trade is significantly affected by financial frictions specific to international transactions.

This paper examines the role of credit market imperfections in trade fluctuations within a general equilibium framework. It introduces working capital financing frictions into an open-economy model with heterogeneous firms in which international trade is more dependent on external finance than domestic sales. The contribution of this study is two-fold. Firstly, the paper proposes a novel mechanism generating a countercyclical external finance premium which arises due to the presence of firms' cash flow constraints, irreversible fixed costs of production and uncertainty concerning firm-specific levels of productivity. In the model developed, financial frictions manifest themselves as labour wedges - discrepancies between the marginal rate of substitution between consumption and leisure and the marginal product of labour. Chari et al. (2007) show that these wedges account for a major part of business cycle fluctuations. Secondly, the paper demonstrates that changes in the cost of external financing in response to changing macroeconomic conditions affect the relative prices of imports and exports, as compared to the prices of goods produced and sold domestically, thereby amplifying the effects of real and financial shocks on international trade and contributing to procyclical movements in the trade to GDP ratio.

While usually absent from trade and macroeconomic models, trade finance plays a crucial role in facilitating international trade. According to Auboin (2009), 80-90\% of international transactions involve some form of credit, insurance or guarantee, whereby about $80 \%$ of total trade finance is of short-term nature. The long time 
lags between production and the receipt of sales revenues involved in international trade, which result from long shipping times and the widespread use of an 'openaccount' payment system in which the exporter is paid only after delivery, as well as the relatively high costs of assessing counterparty risk associated with foreign trading partners, means that international trade is more dependent on external financing than are domestic sales (Amiti and Weinstein 2011). Although initial attempts have been made to provide microfoundations for trade finance and to understand its implications for the behaviour of international trade (Ahn 2011; Schmidt-Eisenlohr 2013; Eck et al. 2014; Antràs and Foley 2015), this paper is the first to examine the impact of financial frictions on trade at business cycle frequency within a general equilibrium framework. ${ }^{1}$ In contrast to previous studies, the proposed model makes it possible to analyse how working capital financing frictions associated with international trade affect the transmission of shocks in an open economy and cyclical fluctuations in international trade.

The mechanism through which financial frictions influence the behaviour of international trade in the model developed in this paper is intuitive. There are two types of firms operating in each economy-domestic retailers, who sell their goods in the domestic market, and exporters, who sell their goods abroad. In order to operate in a given period, firms need to pay in advance a fixed cost of production. They also have to pay for a fraction of their variable costs of production before receiving revenues from sales. Firms need to finance a part of their working capital externally, through short-term bank loans. Due to longer time lags in international trade, documented extensively by Hummels and Schaur (2013) and Djankov et al. (2010), exporters have greater working capital financing requirements and therefore are more dependent on external finance than domestic retailers. Firms are heterogeneous and face uncertainty concerning their individual level of productivity which is only revealed after the irreversible fixed costs of production have been paid and after loan contracts have been arranged. In consequence, in each period a fraction of firms with the lowest productivity incurs losses and defaults on their debt. In order to compensate for the losses generated by defaulting firms, commercial banks charge a premium on their loans. As the fraction of defaulting firms depends on aggregate macroeconomic conditions, the external finance premium varies over time and is negatively correlated with aggregate output. Countercyclical changes in this premium affect firms' marginal cost and prices. Due to the fact that exporters finance a greater fraction of their working capital externally, their prices are more sensitive to changes in the cost of external finance than those of domestic retailers. As a result, the relative price of imported to domestic goods is countercyclical and the trade to GDP ratio moves procyclically. Furthermore, due to the fact that the external finance premium contributes to the difference between the marginal rate of substitution between consumption and leisure and the marginal product of labour, changes in the cost of external finance for

\footnotetext{
${ }^{1}$ The paper contributes to the growing literature on the role of financial markets' imperfections in the business cycle (notable examples include Bernanke et al. 1999, and Kiyotaki and Moore 1997). However, in contrast to existing studies, its focus is on the implications of such frictions for trade. The study complements research on the impact of credit constraints on long-term patterns in international trade (Manova 2013; Chaney 2016).
} 
firms generate procyclical changes in the labour wedge, which are well documented in the data (e.g. Hall 1997; Shimer 2009).

The study demonstrates that credit frictions are able to explain a significant part of the fluctuations of international trade over the business cycle. Changes in the external finance premium resulting from changes in macroeconomic conditions amplify the impact of demand and productivity shocks on trade and generate trade income elasticities of 1.3. The behaviour of international trade is also directly influenced by financial shocks. An increase in the loan financing costs for banks due to increased risk in the financial sector lead to even larger changes in international trade relative to output. The analysis shows that financial frictions substantially contributed to the great trade collapse of 2008-2009.

The prediction of the model that trade finance affects the behaviour of international trade through the marginal cost channel is consistent with the behaviour of relative prices during the global financial crisis. Ahn et al. (2011) show that in 2008 Q4 and 2009 Q1, the period of the greatest decline in international trade, producer prices of exported goods in the European Union, the US and Japan increased substantially, as compared to producer prices of goods sold domestically. Haddad et al. (2010), who decomposed the decrease in international trade into changes in prices and quantities as well as product entry and exit for a number of countries, provide evidence that during the financial crisis import prices of manufactured goods increased, particularly in sectors highly dependent on external finance. Using French firm-level data, Berman et al. (2013) show that export prices increase and export volume declines when the destination country experiences a financial crisis, which is also consistent with the financial accelerator mechanism for imports and exports suggested in this paper.

Not only are the model dynamics consistent with the behaviour of international trade and relative prices during the crisis but they are also in line with the movements in the labour wedge during that time. Kobayashi (2011) and Pescatori and Tasci (2011) demonstrate that the financial crisis was accompanied by a sharp decline in the discrepancy between the marginal rate of substitution between consumption and leisure and the marginal product of labour in the US. In the model developed, real and financial shocks during the crisis are able to explain the large decrease in the labour wedge observed in the data.

The empirical performance of the model and, in particular, its ability to capture the dynamics of international trade, relative prices and wages, was examined with the use of Indirect Inference. The Wald test comparing the estimates of an auxiliary VAR model based on the actual data and based on data simulated from the structural model, could not reject the null hypothesis that the model provides an accurate representation of the data. Monte Carlo simulations confirmed considerable power of the test.

The paper is structured as follows. Section 2 discusses empirical evidence on the cyclical properties of international trade flows and on the changes in international trade, output and prices during the financial crisis of 2008-2009. Section 3 describes the model developed for the purpose of the analysis. Section 4 explains the mechanism through which financial frictions incorporated into the model affect macroeconomic fluctuations. In Section 5, the calibration of the model parameters is outlined. Section 6 presents quantitative results. First, the model's implications for 
the transmission of real and financial shocks to the economy are examined, with a particular focus on international trade flows. Second, the Indirect Inference testing procedure is applied to evaluate the empirical fit of the model and the extent to which it is able to replicate the key features of the data. Finally, the contribution of real and financial shocks to business cycle fluctuations and the dynamics of international trade during the global financial crisis are investigated. The final section concludes.

\section{Empirical Evidence}

The volatility of international trade flows has been shown to be considerably higher than that of output. Engel and Wang (2011) analysed data for 25 OECD countries during the period between 1973 and 2006 and demonstrated that real imports and exports are positively correlated with GDP and that their standard deviations are about two to three times as large as those of output. Kwack et al. (2007) estimated income elasticities of the demand for imports for 30 industrial and Asian countries during the period from 1984 to 2003 . They found that $80 \%$ of these estimates fall in the range from 1.4 to 2.7, with a median and a mean of 1.9. Irwin (2002) and Freund (2009) examined the sensitivity of trade to GDP for the world as a whole and showed that the average elasticity of real trade to real income in the post-war period was 1.7-1.8 and that it increased to over 3.0 in the last two decades.

While an economic downturn is usually accompanied by a decrease in imports and exports which exceeds that of GDP, during the global financial crisis of 2008-2009 world trade experienced an unprecedented decline, comparable in scale only to that which occurred during the Great Depression. ${ }^{2}$ Between September 2008 and March 2009, the six months following the Lehman Brothers' collapse, the volume of international trade decreased globally by $16 \%$ (Fig. 1). The fall in trade was synchronised across countries and strongly affected both advanced and emerging economies. While the financial crisis was accompanied by a strong decline in output, the decrease in imports and exports considerably surpassed that of industrial production and GDP.

It has been suggested that one of the factors contributing to the severe decline in international trade was the increased cost and reduced availability of trade finance during the crisis. The turmoil in financial markets was accompanied by a sharp, universal increase in the cost of trade finance instruments. According to the IMF/BAFT-IFSA Trade Finance Survey from July 2009, between 2007 Q4 and 2009 Q2 the price of trade-related lending and letters of credit increased by about 50-70 basis points from their normal levels of 10 to 15 basis points over the costs of funds, while the cost of export credit insurance rose by about 40 basis points. In some emerging economies spreads on letters of credit increased to 250-600 basis points over the interbank rate (Auboin 2009). The trade finance surveys indicate that banks' rising costs of funds and an increase in default risk associated with international trade were the main reasons behind the rising cost of trade finance instruments.

\footnotetext{
${ }^{2}$ The collapse of international trade is comprehensively documented in Baldwin (2009).
} 


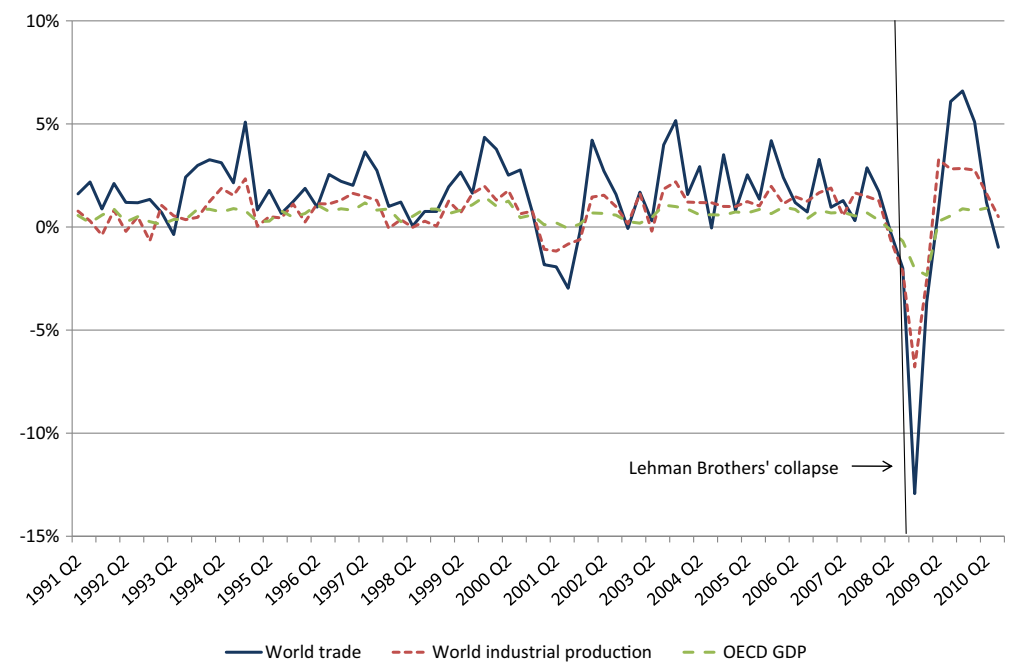

Fig. 1 Trade, industrial production and GDP - annual rates of growth. Source: Netherlands Bureau for Economic Policy Analysis (CPB), OECD Main Economic Indicators

A number of empirical studies indicated that adverse credit conditions contributed to the decline in international trade in 2008 and 2009. Chor and Manova (2012) showed that countries with relatively higher interbank lending rates recorded relatively lower exports to the US and that exports of industries highly dependent on external finance in those countries were particularly severely affected during the crisis. Bricongne et al. (2012) conducted a detailed study of the export performance of French firms during the time of the crisis using firm-level data matching firms' exports with their financial constraints. While the authors found that the decline in trade was predominantly due to a large negative demand shock, they also showed that the tightening of credit market conditions had a significant negative impact on the exports of financially constrained firms. Paravisini et al. (2015) analysed matched credit-export data for Peru and demonstrated that changes in the supply of credit during the crisis had a strong negative effect on Peruvian exports.

The negative impact of shocks originating in financial markets on international trade was not only a feature of the recent crisis, but was also observed during other periods of financial turbulence. Amiti and Weinstein (2011) showed that exports are more sensitive than domestic sales to financial sector shocks by using matched firmbank data from the Japanese financial crisis of the 1990s. They found that Japanese firms reduced their exports relative to domestic sales when the financial situation of banks financing them deteriorated. The authors estimated that the financial shocks were responsible for about one-third of the decline in Japanese exports during the crisis. Iacovone and Zavacka (2009), who analysed data from 23 banking crises in developed and developing countries between 1980 and 2000, also found that financial shocks are an important source of trade fluctuations. They demonstrated that during a crisis in the banking sector, the exports of industries more dependent on external 
finance suffer relatively more than the exports of sectors less dependent on external financing. Berman and Martin (2012) showed within a gravity framework that countries which are more dependent on trade finance experience larger declines in exports in times of financial or currency crisis.

A negative relationship between firms' external finance dependence and their performance during a financial crisis is not confined to exporting firms. Kroszner et al. (2007), using data from 38 developed and developing countries in the last quarter of the twentieth century, found that during a banking crisis sectors which require extensive external financing tend to experience a substantially greater contraction of value added. Similar results were obtained by Dell'Ariccia et al. (2008) for a panel of 41 countries from 1980 to 2000 . The degree of external finance dependence not only affects firms' performance during a banking crisis but also over the business cycle. Braun and Larrain (2005) examined production growth for 28 manufacturing industries in 111 countries over nearly four decades and showed that industries which are more dependent on external finance are more strongly affected during recessions. These results suggest that it is not necessarily the differences in the nature of financial instruments used to finance domestic and international transactions but rather the differences in the dependence on external financing associated with these transactions per se that make international trade more sensitive than domestic sales to real and financial shocks.

In view of the empirical evidence, the mechanism through which the degree of external finance dependence affects firms' export performance in response to shocks needs to be examined. Bricongne et al. (2012), Paravisini et al. (2015) and Haddad et al. (2010) showed that the fall in trade during the financial crisis of 2008 and 2009 was mostly along the intensive margin, which suggests that adverse financial conditions depressed exports mainly by affecting firms' marginal costs and their relative prices. The dynamics of prices during the crisis support this hypothesis. As noted by Ahn (2011) and Ahn et al. (2011), the increase in the cost of trade finance in 2008 and 2009 was accompanied by changes in the relative prices of export to domestic goods. While the financial crisis led to a decline in producer prices in the US, the European Union and Japan, in all these economies, which in 2009 jointly accounted for over half of world exports, the prices of exported goods increased relative to the prices of goods sold domestically. Following the bankruptcy of the Lehman Brothers, the growth rate of producer prices of non-agricultural export goods in the US in the period from September 2008 to March 2009 was by 9 percentage points higher than the growth rate of producer prices of all industrial commodities (Fig. 2). The relative export price increased despite the fact that the US dollar appreciated at the same time. An increase in the relative export price was also observed in the Euro Area. Between September 2008 and March 2009 domestic producer prices of manufactured goods decreased when compared to the producer prices of goods exported to countries both inside and outside the Euro Area, which suggests that the relative price movements were not driven by changes in the exchange rate (Fig. 3). A similar increase in the relative price of exports during the crisis was also recorded in Japan (Ahn et al. 2011).

Haddad et al. (2010) conducted a comprehensive analysis of imports to the United States, the European Union, Indonesia and Brazil during the period from 2008 to 


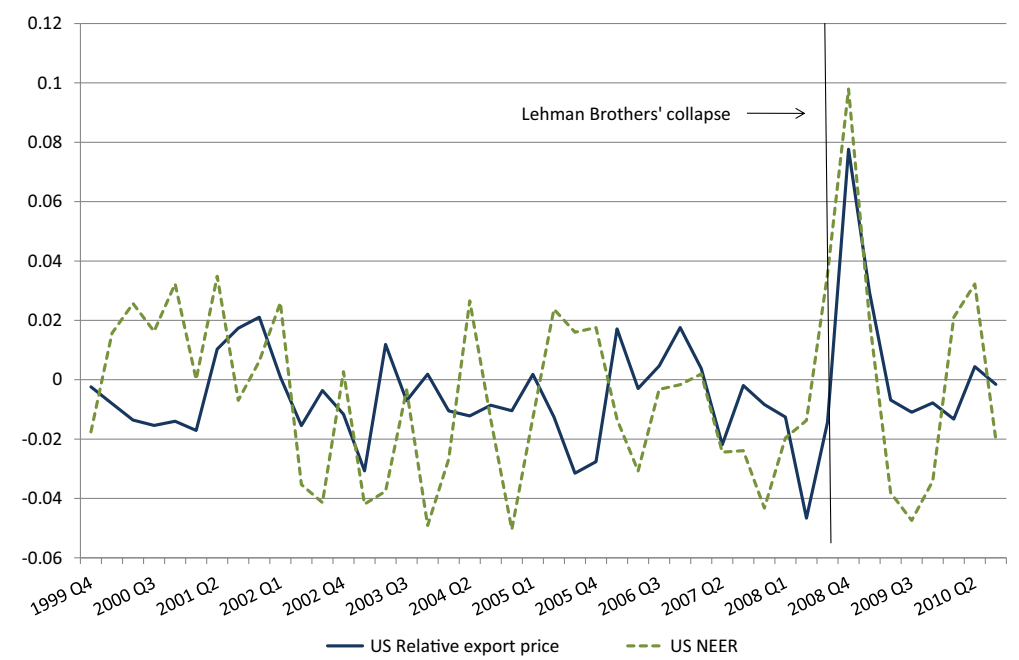

Fig. 2 The growth rate of US non-agricultural export prices minus the growth rate of producer prices for industrial commodities and the rate of change of nominal effective exchange rate. Source: Bureau of Labor Statistics, OECD Main Economic Indicators

2009. They found that while in all countries under consideration except for Brazil aggregate import prices decreased during the crisis, their decline was primarily driven by the fall in the prices of commodities. In all countries covered by the analysis, the prices of manufactured import goods increased, which indicates that supply shocks played a role. The authors showed that in the United States the most significant price increases were recorded in sectors which are highly dependent on external finance,

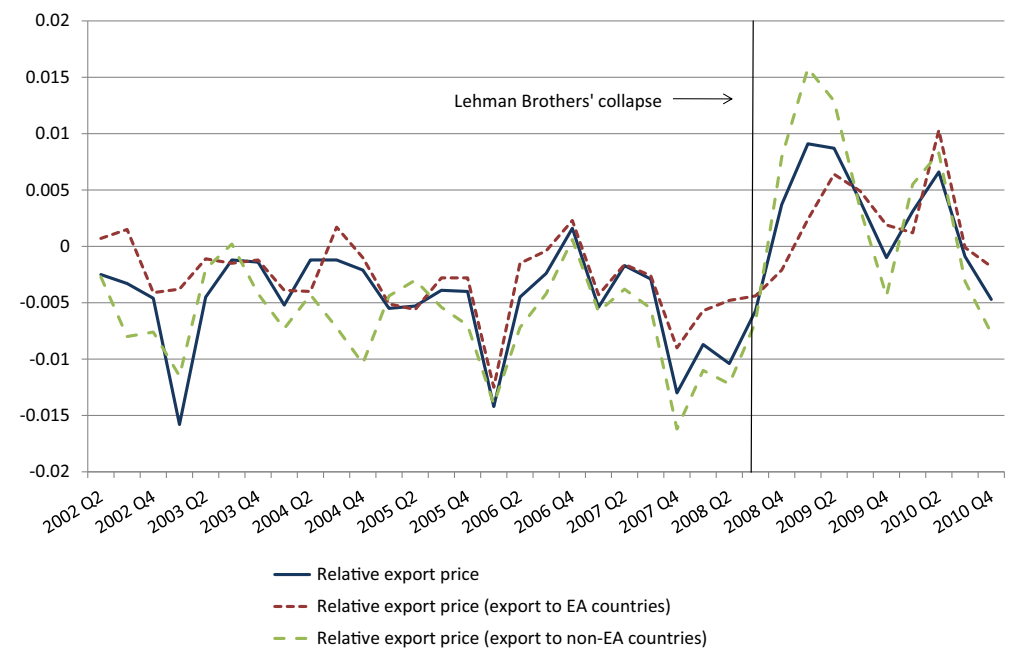

Fig. 3 The growth rate of producer prices for exports minus the growth rate of producer prices for domestic goods in the Euro Area. Source: Eurostat 
which supports the view that credit market imperfections contributed to the decline in trade during the crisis through the marginal cost channel.

A striking feature of the financial crisis was a dramatic decline in the labour wedge. While the labour wedge is in general strongly procyclical, its decline during the crisis was exceptionally large. Kobayashi (2011) shows that in the period from 2008 Q2 to 2009 Q2 the labour wedge in the US declined by 9.2\% (Fig. 4). This evidence is consistent with the view that financial market imperfections, which played an important role during the crisis, may manifest themselves as labour wedges.

In line with the empirical evidence, the next section develops a model in which due to differences in external financing needs associated with domestic and international transactions, changes in the cost of external finance driven by changes in macroeconomic conditions affect international trade through their impact on the relative price of exported and domestic goods.

\section{Model}

The paper introduces cash flow constraints into an open-economy flexible price general equilibrium model with heterogeneous firms. The world economy consists of two identical countries: Home and Foreign. Each country is populated by households, entrepreneurs and bankers. Households consume goods and supply labour to firms and banks. Entrepreneurs set up and manage firms producing differentiated consumption goods which are sold in monopolistically competitive markets either in the domestic or in the foreign economy. Bankers run perfectly competitive commercial banks which collect deposits from households and grant loans to firms. The economies are subject to real shocks to productivity and demand as well as financial shocks affecting the cost of credit in the economy.

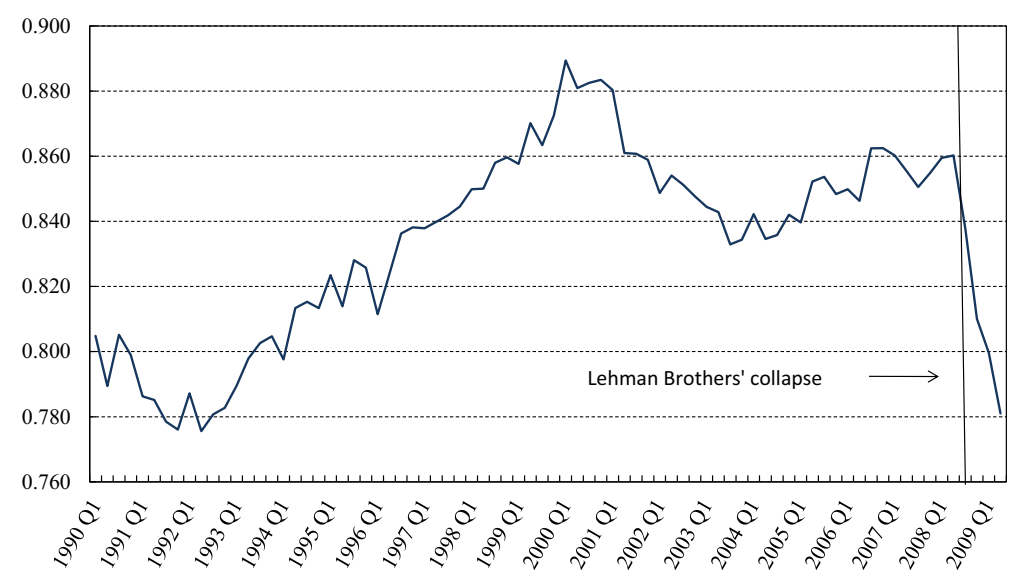

Fig. 4 Labour wedge in the US. Source: Kobayashi 2011 


\subsection{Households}

Each country is inhabited by a continuum of identical, infinitely-lived households located in the interval $[0,1]$. Households provide labour to firms and banks and derive utility from consumption and leisure. Their utility function is additively separable in consumption, $C_{t}$, and labour, $L_{t}$, and given by:

$$
E_{t} \sum_{k=0}^{\infty} \beta^{k}\left[\frac{C_{t+k}^{1-\sigma}}{1-\sigma} U_{t+k}-\frac{L_{t+k}^{1+\varphi}}{1+\varphi}\right]
$$

where $\beta \in(0,1)$ is the intertemporal discount factor, $\sigma>0$ is the inverse of the intertemporal elasticity of substitution in consumption, $\varphi \geq 0$ is the inverse of the Frisch elasticity of labour supply, $U_{t}$ captures shocks to the marginal utility of consumption such that $\ln U_{t}=\rho_{u} \ln U_{t-1}+\xi_{t}^{u}$ where $\rho_{u} \in\langle 0,1)$ and $\xi_{t}^{u} \sim N\left(0, \sigma_{u}^{2}\right)$.

Households maximise their expected discounted lifetime utility subject to a sequence of budget constraints:

$$
P_{t} C_{t}+E_{t}\left[Q_{t, t+1} D_{t+1}\right]=W_{t} L_{t}+D_{t}+I_{t}+\left(R_{H}-1\right) J_{t}
$$

where $P_{t}$ is the aggregate price level in the Home economy at time $t, Q_{t, t+1}$ is the stochastic discount factor for one-period ahead nominal payoffs, $D_{t+1}$ is the nominal payoff in period $t+1$ of the portfolio held at the end of period $t$, whereby it is assumed that in both countries households have unrestricted access to a complete set of contingent claims traded internationally. $W_{t}$ denotes nominal wage and $I_{t}$ is a lump sum component of households' income including dividends from the ownership of firms. The last term on the right hand side of the equation denotes households' income from intra-period deposits held at commercial banks, where $J_{t}$ denotes the value of these deposits and $R_{H}$ is the return.

Households receive their salaries at the beginning of each period. Each household spends a fraction of its salary immediately to purchase Arrow-Debreu securities and to make advance payments for consumption goods. The rest of the salary is kept on short-term, intra-period deposits in banks, which in turn use them to finance loans to firms. At the end of the period, the deposits are withdrawn and used to pay for goods which are consumed in the same period. Due to the facts that holding bank deposits is risk-free, that deposits are held entirely within a period and that the only alternative to holding deposits is to keep cash, households' opportunity cost is equal to one and the deposits bear zero interest rate $\left(R_{H}=1\right)$, as in Carlstrom and Fuerst (1998).

Households' consumption aggregator in the Home economy, $C_{t}$, is of the CES form and is given by:

$$
C_{t}=\left(\alpha^{\frac{1}{\theta}} C_{D, t}^{\frac{\theta-1}{\theta}}+(1-\alpha)^{\frac{1}{\theta}} C_{I, t}^{\frac{\theta-1}{\theta}}\right)^{\frac{\theta}{\theta-1}}
$$


where $\theta$ is the elasticity of substitution between any two varieties such that $\theta>0$ and $\alpha \in(0,1)$ determines the share of domestically produced goods in consumption. $C_{D, t}$ is the consumption aggregator of domestic goods, indexed by $j$, such that:

$$
C_{D, t}=\left[\int_{0}^{1} C_{D, j, t}^{\frac{\theta-1}{\theta}} d j\right]^{\frac{\theta}{\theta-1}}
$$

$C_{I, t}$ is the corresponding consumption aggregator of imported goods:

$$
C_{I, t}=\left[\int_{0}^{1} C_{I, j, t}^{\frac{\theta-1}{\theta}} d j\right]^{\frac{\theta}{\theta-1}}
$$

where $C_{I, j, t}=C_{E, j, t}^{*}$ and $C_{E, t}^{*}$ is the consumption aggregator of varieties exported from the Foreign economy such that $C_{E, t}^{*}=C_{I, t} \cdot{ }^{3}$

The utility-based aggregate consumption price index is therefore equal to:

$$
P_{t}=\left[\alpha P_{D, t}^{1-\theta}+(1-\alpha) P_{I, t}^{1-\theta}\right]^{\frac{1}{1-\theta}}
$$

where

$$
P_{D, t}=\left[\int_{0}^{1} P_{D, j, t}^{1-\theta} d j\right]^{\frac{1}{1-\theta}} \text { and } P_{I, t}=\left[\int_{0}^{1} P_{I, j, t}^{1-\theta} d j\right]^{\frac{1}{1-\theta}}
$$

$P_{I, j, t}=S_{t} P_{E, j, t}^{*}$ where $P_{E, j, t}^{*}$ is the price of the variety produced by firm $j$, exported from the Foreign economy and expressed in Foreign currency, $S_{t}$ is the nominal exchange rate, expressed as the price of one unit of the Foreign currency in terms of the Home currency.

The solution to the household decision problem gives a set of first-order equilibrium conditions. The intratemporal condition for labour supply is given by:

$$
\frac{W_{t}}{P_{t}}=\frac{C_{t}^{\sigma} L_{t}^{\varphi}}{U_{t}}
$$

Optimal portfolio allocation results in the following intertemporal consumption Euler equation for the Home economy:

$$
C_{t}^{-\sigma} U_{t}=\beta E_{t}\left[C_{t+1}^{-\sigma} U_{t+1} \frac{1}{Q_{t, t+1}} \frac{P_{t}}{P_{t+1}}\right]
$$

while the consumption Euler equation for the Foreign economy takes the form:

$$
C_{t}^{*-\sigma} U_{t}^{*}=\beta E_{t}\left[C_{t+1}^{*-\sigma} U_{t+1}^{*} \frac{1}{Q_{t, t+1}} \frac{S_{t} P_{t}^{*}}{S_{t+1} P_{t+1}^{*}}\right]
$$

\footnotetext{
${ }^{3}$ Throughout the paper, Foreign variables are denoted by an asterisk.
} 
Combining conditions (8) and (9) and assuming that initially the two economies are perfectly symmetric leads to the well-known risk-sharing condition:

$$
\left(\frac{C_{t}}{C_{t}^{*}}\right)^{\sigma} \frac{U_{t}^{*}}{U_{t}}=\frac{S_{t} P_{t}^{*}}{P_{t}}
$$

which equalises the marginal utility of consumption across countries, weighted by the relative price of consumption in these countries.

\subsection{Firms}

In each economy there is a large number of profit-maximising entrepreneurs. As in Fuerst (1995), it is assumed that entrepreneurs live only one period. At the beginning of each period, entrepreneurs set up one-period firms. A continuum of entrepreneurs, indexed by $j$, ranging from 0 to 1 , start up domestic retail firms, which produce differentiated goods for sale only in the Home market, and a continuum of entrepreneurs, also indexed by $j$, ranging from 1 to 2 establish exporting firms, which serve only the Foreign market. When starting up their businesses in a given period, entrepreneurs know neither the macroeconomic conditions prevailing in that period nor their own level of productivity, which is firm-specific. The realisation of both aggregate and idiosyncratic shocks is only revealed once production starts. Entrepreneurs face cash flow constraints. They need to pay firm start-up costs and the variable costs of production at the beginning of the period, but they do not possess any initial wealth and they only receive a part of their sales revenues in advance. The production costs which cannot be covered from these sales pre-payments are financed externally, by borrowing funds from households through commercial banks. Exporters need to finance a greater fraction of their working capital externally than do domestic retailers.

\subsubsection{Production Function}

Setting-up a firm is costly. Before a firm starts operating, entrepreneurs have to incur a fixed, irreversible cost of $F_{X}$ units of effective labour, equal to $\frac{W_{t} F_{X}}{Z_{t}}$, where $X \in\{D, E\}$. Throughout the paper, the subscripts $D$ and $E$ denote variables corresponding to domestic retailers and exporters, respectively. $Z_{t}$ is an aggregate level of productivity at time $t$, which is subject to shocks such that $\ln Z_{t}=\rho_{z} \ln Z_{t-1}+\xi_{t}^{z}$ where $\rho_{z} \in\langle 0,1)$ and $\xi_{t}^{z} \sim N\left(0, \sigma_{z}^{2}\right)$. Having paid set-up costs, firms then produce differentiated goods using a simple production technology with constant returns to scale in which domestic labour is the only factor of production. The production function is given by:

$$
Y_{X, j, t}=Z_{t} A_{X, j, t} L_{X, j, t}
$$

where $Y_{X, j, t}$ is the output, at time $t$, of firm $j$ in sector $X$ and $L_{X, j, t}$ is the firm's labour input at time $t$. Firms' productivity depends on two components: $Z_{t}$, which is an aggregate level of productivity at time $t$, common for all firms in the economy, 
and $A_{X, j, t}$, which is a firm-specific level of productivity. ${ }^{4}$ Following Ghironi and Melitz (2005), it is assumed that the individual component of firms' productivity, $A$, is Pareto distributed ${ }^{5}$ with the cumulative distribution function $F(A)=1-\left(\frac{A_{\min }}{A}\right)^{k}$. The parameters $A_{\min }$ and $k>\theta-1$ determine the lower bound and the dispersion of firms' productivity, respectively. The firm-specific productivity distribution is the same for domestic retailers and exporting firms and is time-invariant.

\subsubsection{External Financing}

At the beginning of each period firms need to pay for their fixed and variable costs of production and do not have sufficient internal funds to do so. Advance payments which firms receive for their goods at the beginning of each period cover a fraction of the variable costs of production equal to $\left(1-d_{D}\right)$ in the case of domestic retailers and $\left(1-d_{E}\right)$ in the case of exporters, where $d_{D} \in\langle 0,1\rangle$ and $d_{E} \in\langle 0,1\rangle$. In order to finance the remaining working capital, as well as the fixed costs of production, firms apply for short-term, intra-period bank loans, which are backed by their future revenues from sales.

The fraction of the variable costs of production which needs to be financed externally, given by $d_{X}$, is exogenous, sector-specific and it is assumed that $d_{E}>d_{D}$. The assumption that exporting firms have relatively greater working capital external finan-

cing needs reflects the fact that due to longer shipping times and the additional time required to complete administrative procedures associated with imports and exports, the cash conversion cycle in international trade is longer than in domestic sales. ${ }^{6}$

When applying for bank loans, entrepreneurs face uncertainty concerning the aggregate macroeconomic shocks as well as the firm-specific component of their productivity. However, as the expected profits are positive for all firms and banks are able to hedge against credit risk, all entrepreneurs are granted a loan. The debt contracts signed between entrepreneurs and commercial banks at the beginning of each period specify the magnitude of the loan, $D_{X, j, t}$, the interest rate on the loan, $\left(R_{X, t}-1\right)$, a fixed financial intermediation fee of $G_{X}$ effective labour units, equal to $\frac{W_{t} G_{X}}{Z_{t}}$, and the collateral, $T_{X, j, t}$, which the bank receives at the end of the period if firm $j$ is unable to pay back the whole value of the loan with the interest due.

The loan contracts are signed before the aggregate and firm-specific shocks are observed; however, they are state-contingent. The interest rate on bank loans depends

\footnotetext{
${ }^{4}$ The assumption that firm-specific risk is a major source of firms' uncertainty is consistent with empirical evidence provided by Castro et al. (2015), who show that idiosyncratic risk accounts for about $90 \%$ of the overall uncertainty faced by firms.

${ }^{5}$ The assumption of a Pareto distribution for productivity draws implies that the distribution of firms' size is also Pareto, which, as shown by Axtell (2001), is consistent with US firm-level data.

${ }^{6}$ While in this paper the degree of external finance dependence is exogenous and it is assumed that exporters have greater working capital external financing requirements than domestic retailers, Feenstra et al. (2014) show that this difference between exporting and non-exporting firms arises endogenously in a model which explicitly incorporates the longer time-lags involved in the shipping of exports and in which exporters incur additional fixed cost.
} 
on the realisation of aggregate shocks in a given period, while the size of the loan and the collateral are determined by both the aggregate and firm-specific shocks. At the beginning of each period the expected profits are the same for all firms within a particular sector and, as a result, the cost of credit is also the same for all firms within each sector.

A loan granted by a bank can be interpreted as an open credit line with a variable interest rate. The magnitude of firm $j$ 's loan, $D_{X, j, t}$, is chosen by firms optimally (with the constraint that it must cover at least the fixed costs of production) after their individual levels of productivity in a given period are revealed. In each period firms borrow funds which, for their given level of productivity, are needed to produce the profit-maximising level of output. The magnitude of the loan is therefore equal to the value of the fixed costs of setting up a firm and receiving a loan as well as a fraction $d_{X, t}$ of the variable cost of production:

$$
D_{X, j, t}=\frac{W_{t}}{Z_{t}}\left(F_{X}+G_{X}\right)+d_{X, t} Y_{X, j, t} \frac{W_{t}}{Z_{t} A_{X, j, t}}
$$

The profit-maximising output of firm $j$ at time $t$ in sector $X$, given by $Y_{X, j, t}$, is equal to the demand for firm $j$ 's variety. In the case of domestic retailers, this demand is equal to:

$$
C_{D, j, t}=\alpha\left(\frac{P_{D, j, t}}{P_{t}}\right)^{-\theta} C_{t}
$$

where $P_{D, j, t}$ is the price of firm $j$ 's variety.

In turn, the demand for the variety produced by an exporting firm $j$ is equal to:

$$
C_{E, j, t}=(1-\alpha)\left(\frac{P_{I, j, t}^{*}}{P_{t}^{*}}\right)^{-\theta} C_{t}^{*}
$$

where $P_{I, j, t}^{*}=\frac{1}{S_{t}} P_{E, j, t}$ is the price of firm $j$ 's variety in units of Foreign currency.

Both domestic retailers and exporters sell their goods in a monopolistically competitive environment. Their prices are set optimally and are equal to a constant mark-up over marginal cost:

$$
P_{X, j, t}=\mu \frac{W_{t}}{Z_{t} A_{X, j, t}} \widetilde{R}_{X, t}
$$

where $P_{X, j, t}$ is the price of the good produced by firm $j$ in sector $X$ at time $t, \mu$ is the firm's mark-up $\mu=\frac{\theta}{\theta-1}$ and $\widetilde{R}_{X, t}$ is firm $j$ 's effective borrowing cost equal to:

$$
\widetilde{R}_{X, t}=\left(1-d_{X}\right)+d_{X} R_{X, t}
$$

The collateral that is offered to the bank on a loan to firm $j$ is equal to the value of firm $j$ 's sales revenues net of its labour costs of production financed from these revenues and is given by:

$$
T_{X, j, t}=Y_{X, j, t} P_{X, j, t}-\left(1-d_{X}\right) Y_{X, j, t} \frac{W_{t}}{Z_{t} A_{X, j, t}}
$$


At the end of the period, after receiving revenues from sales, firm $j$ 's profits, $\Pi_{X, j, t}$, amount to:

$$
\Pi_{X, j, t}=Y_{X, j, t} P_{X, j, t}-Y_{X, j, t} \frac{W_{t}}{Z_{t} A_{X, j, t}} \widetilde{R}_{X, t}-\frac{W_{t}}{Z_{t}}\left(F_{X}+G_{X}\right) R_{X, t}
$$

If $\Pi_{X, j, t} \geq 0$, firm $j$ pays $D_{X, j, t} R_{X, t}$ to the bank and keeps the remaining profits, which are then transferred to households in the form of dividends. If $\Pi_{X, j, t}<0$, then the firm declares bankruptcy and gets nothing whereas the bank receives the collateral net of the cost of recovering it, which is equal to a fraction $H_{X} \in\langle 0 ; 1\rangle$ of the sales revenues remaining at the firm at the time of default.

\subsection{Banks}

In each economy, there is a large number of identical, perfectly competitive commercial banks. Banks hold households' deposits and provide loans to firms. Following Carlstrom and Fuerst (1998), it is assumed that both deposits and loans are held only within a period (intra-period deposits and loans). The deposits are put down at the beginning of the period and withdrawn at the end of the same period. Due to fact that they bear no risk and that households have no alternative investment opportunities within the time frame during which they are held, the interest rate on these deposits is equal to zero. Loans to firms are also granted and repaid in the course of one period - the funds are transferred to entrepreneurs after the period started and are repaid before the period ends. All banks have an equal share in all loan contracts and, at the end of the period, they receive the same loan repayments.

\subsubsection{Loan Financing Costs}

In each period banks are subject to exogenous death shocks occurring with probability $\varpi_{t}$ which varies over time. ${ }^{7}$ Bank death shocks are timed to take place after households' have deposited their funds in the banks and before banks grant loans to entrepreneurs. A bank's death is associated with a deadweight loss equal to the value of all deposits held at that bank. In order to ensure that bank deposits are riskfree, banks set up a deposit guarantee scheme. In each period they pay a fraction of their total assets into a mutual fund, which is then drawn upon in order to repay all households the full value of their deposits.

Due to the fact that in each period a fraction $\varpi_{t}$ of banks dies and that the resulting deadweight loss is covered by the remaining banks, in order to provide one unit of

\footnotetext{
${ }^{7}$ The assumption of an exogenous probability of a bank's death is introduced in order to allow for changes in banks' own cost of funds. As banks do not pay any interest on deposits, in the absence of banks' death, banks' marginal cost of financing a loan would be constant and equal to 1 . In the model, firms' defaults do not lead to banks' failure but only to changes in the cost of bank lending. This is because banks set the interest rates on loans after the realisation of shocks (the debt contract is state-contingent) and they are set at the level at which the loan repayments from non-defaulting firms cover the losses imposed by defaulting firms.
} 
loans to firms banks need to secure $\frac{1}{B_{t}}$ units of households' deposits, where $B_{t}=$ $\left(1-\varpi_{t}\right)$ is the probability of a bank's survival such that $\ln B_{t}=\rho_{b} \ln B_{t-1}+\xi_{t}^{b}$ with $\rho_{b} \in\langle 0,1)$ and $\xi_{t}^{b} \sim N\left(0, \sigma_{b}^{2}\right)$. As a result, the marginal cost of financing a bank loan, given by $M_{t}$, is equal to:

$$
M_{t}=\frac{1}{B_{t}} R_{H}=\frac{1}{B_{t}}
$$

The cost of providing external finance to entrepreneurs in a given period is therefore determined by the time-varying probability of a bank's survival, $B_{t}$. The lower the probability of a bank's survival, the greater fraction of banks' assets is used to cover for the deadweight loss resulting from banks' death and the greater the loan financing cost. As the costs of providing external finance to firms are passed on to the entrepreneurs, they are reflected in the interest rates charged on bank loans.

\subsubsection{Debt Contract}

The total value of loans granted to entrepreneurs in sector $X$ is equal to:

$$
\int_{A_{\min }}^{\infty} D_{X, j, t} d F(A)
$$

In each period a fraction of firms in sector $X$ with idiosyncratic productivity draws such that $A_{X, j, t}<\bar{A}_{X, t}$ incurs losses and defaults on their debt, where $\bar{A}_{X, t}$ is the threshold level of idiosyncratic productivity at time $t$ above which a firm in sector $X$ is able to fulfill all its financial obligations. The threshold level of productivity $\bar{A}_{X, t}$ is determined by the condition that the profit of the firm with the idiosyncratic productivity $\bar{A}_{X, j, t}=\bar{A}_{X, t}$ is equal to zero:

$$
Y_{X, j, t} P_{X, j, t}-Y_{X, j, t} \frac{W_{t}}{Z_{t} \bar{A}_{X, j, t}} \widetilde{R}_{X, t}-\frac{W_{t}}{Z_{t}}\left(F_{X}+G_{X}\right) R_{X, t}=0
$$

At the end of the period, banks receive from firm $j$ the value $D_{X, j, t} R_{X, t}$ if $A_{X, j, t} \geq$ $\bar{A}_{X, t}$, where $\operatorname{Pr}\left(A_{X, j, t} \geq \bar{A}_{X, t}\right)=1-F\left(\bar{A}_{X, t}\right)$. In the case when $A_{X, j, t}<\bar{A}_{X, t}$, where $\operatorname{Pr}\left(A_{X, j, t}<\bar{A}_{X, t}\right)=F\left(\bar{A}_{X, t}\right)$, the banks receive a fraction $\left(1-H_{X}\right)$ of the value of all firms' revenues remaining at the firm at the time of bankruptcy $T_{X, j, t}$, whereby $H_{X}$ determines the loan recovery costs. The fraction of defaulting firms in sector $X$ is equal to $N_{X, t}=F\left(\bar{A}_{X, t}\right)$.

The interest rate $\left(R_{X, t}-1\right)$ on a bank loan in sector $X$ is determined by the condition that the total value of loan repayment, which banks receive at the end of the 
period, must be equal to the total cost of financing these loans. Banks' participation constraint is therefore given by:

$$
\begin{aligned}
& \int_{\bar{A}_{X, t}}^{\infty} D_{X, j, t} R_{X, t} d F(A) \\
& \quad+\left(1-H_{X}\right) \int_{A_{\min }}^{\bar{A}_{X, t}}\left[Y_{X, j, t} P_{X, j, t}-\left(1-d_{X}\right) Y_{X, j, t} \frac{W_{t}}{Z_{t} A_{X, j, t}}\right] d F(A) \\
& =M_{t} \int_{A_{\min }}^{\infty} D_{X, j, t} d F(A)
\end{aligned}
$$

Banks are perfectly competitive and, as a result, their profits from providing financial intermediation between households and firms are equal to zero.

Following Melitz (2003), we can define the following productivity averages. The average firm-specific level of productivity among defaulting firms in sector $X$ is equal to:

$$
A_{X L, t}=\left[\frac{1}{F\left(\bar{A}_{X, t}\right)} \int_{A_{\min }}^{\bar{A}_{X, t}} A^{\theta-1} d F(A)\right]^{\frac{1}{\theta-1}}
$$

The average firm-specific productivity among non-defaulting firms in sector $X$ is given by:

$$
A_{X H, t}=\left[\frac{1}{1-F\left(\bar{A}_{X, t}\right)} \int_{\bar{A}_{X, t}}^{\infty} A^{\theta-1} d F(A)\right]^{\frac{1}{\theta-1}}
$$

The average level of the idiosyncratic component of firms' productivity is timeinvariant, the same for both sectors and equal to:

$$
A_{X A}=\left[\int_{A_{\min }}^{\infty} A^{\theta-1} d F(A)\right]^{\frac{1}{\theta-1}}
$$

Using the Pareto distribution, the average productivities can now be expressed in terms of the threshold level of productivity and the default rate:

$$
\begin{gathered}
A_{X A}=\left[\frac{k}{k-(\theta-1)}\right]^{\frac{1}{\theta-1}} A_{\min } \\
A_{X H, t}=\left[\frac{k}{k-(\theta-1)}\right]^{\frac{1}{\theta-1}} \bar{A}_{X, t} \\
A_{X L, t}=\left[\frac{k}{k-(\theta-1)}\right]^{\frac{1}{\theta-1}}\left[\frac{1}{N_{X, t}} A_{\min }^{\theta-1}-\frac{\left(1-N_{X, t}\right)}{N_{X, t}}\left(\bar{A}_{X, t}\right)^{\theta-1}\right]^{\frac{1}{\theta-1}}
\end{gathered}
$$


The banks' participation constraint (21), the firms' zero profit condition (20) and the equations determining aggregate productivities (Eqs. 25, 26 and 27) together determine the interest rate on bank loans, $\left(R_{X, t}-1\right)$, the threshold level of productivity, $\bar{A}_{X, t}$, and the default rate among firms, $N_{X, t}$, for given levels of aggregate shocks.

\subsection{Resource Constraints}

Equilibrium in the labour market requires that in each country the labour employed by domestic retailers and exporters to produce goods, to provide financial intermediation and to set up firms is equal to the domestic labour supply. The labour market equilibrium condition for the Home economy is therefore given by:

$$
L_{t}=L_{D, t}+L_{E, t}+\frac{1}{Z_{t}}\left(F_{D}+G_{D}+F_{E}+G_{E}\right)
$$

The goods market is in equilibrium when the supply of goods produced by domestic retailers and exporters is equal to the demand for these goods and hence:

$$
Y_{D, t}=C_{D, t}
$$

and

$$
Y_{E, t}=C_{I, t}^{*}
$$

The model is closed by setting the Home price index equal to one: $P_{t}=1$. The nominal exchange rate is also set equal to one: $S_{t}=1$ without loss of generality. ${ }^{8}$

\section{Financial Frictions and the Macroeconomy}

The presence of cash flow constraints has a number of implications for the steady state and the business cycle properties of the model. The purpose of this section is to discuss the intuition behind the mechanism through which these frictions affect the equilibrium of the economy and macroeconomic dynamics. For this purpose, it is first helpful to consider the case in which macroeconomic and financial shocks are symmetric across countries and in which the degree of external finance dependence of exporters and domestic retailers is the same, $d_{E}=d_{D}=d$.

The model has the property that as long as the fixed costs of production are large enough to generate a positive default rate among firms or there is a risk of a bank's failure, firms need to pay a premium on external finance, $\left(R_{t}-1\right)>0$. Due to the presence of credit risk and/or a positive probability of a bank's death, the interest rate charged on bank loans is greater than zero, even though banks pay zero interest on households' deposits. The loan repayments by firms with positive profits need to compensate for the losses generated by firms which are not able to pay back the total value of their debt and for the losses associated with a bank's death.

\footnotetext{
${ }^{8}$ A complete set of the model's equilibrium conditions for the Home economy is provided in Appendix A.1, while Appendix A.2 presents the equilibrium conditions in their log-linearized form.
} 
The external finance premium is countercyclical. Positive demand and productivity shocks resulting in an increase in output lead to higher profits and lower default rates among firms. In consequence, a smaller proportion of revenues received by profitable firms is sufficient to cover the losses that banks incur on loans granted to defaulting firms. As a result, the external finance premium decreases. By contrast, during an economic downturn, banks need to raise borrowing costs in order to finance the losses induced by a greater number of defaulting firms and the external finance premium increases. This premium is also affected by financial shocks which lead to changes in banks' own cost of funds and it increases with the probability of a bank's failure.

If the external finance premium is positive, $R_{t}>1$, and firms are cash flow constrained, $d>0$, then firms' effective borrowing cost is greater than one, $\widetilde{R}_{t}>1$. Through its impact on the effective borrowing cost, firms' cash flow constraints affect the aggregate level of output in the economy. This can be seen by considering firms' employment decisions and households' intratemporal consumption-leisure choice. Firms' profit maximisation requires that the real wage is equal to a constant fraction of the real marginal revenue product of labour:

$$
\frac{W_{t}}{P_{t}}=\frac{Z_{t} A_{A}}{\mu \widetilde{R}_{t}}
$$

At the same time, in a perfectly competitive labour market the real wage is equal to the marginal rate of substitution between consumption and leisure:

$$
\frac{W_{t}}{P_{t}}=\frac{C_{t}^{\sigma} L_{t}^{\varphi}}{U_{t}}
$$

To the extent to which the effective borrowing cost is greater than one, it generates a labour wedge - a discrepancy between the marginal rate of substitution between consumption and leisure and the average marginal product of labour across firms, equal to $Z_{t} A_{A}$. This wedge leads to an inefficiently low aggregate level of output. When the effective borrowing cost is greater than one, then for a given marginal product of labour, the real wage is lower than in the case when the effective borrowing cost is equal to one. As a result, the equilibrium level of labour supply, which equates the marginal rate of substitution between consumption and leisure with the real wage, is also lower, leading to a relatively lower level of output.

Due to the fact that the external finance premium is countercyclical, the effective borrowing cost is also countercyclical, which in turn leads to a procyclical labour wedge. This is an important feature of the model as it demonstrates that working capital financing frictions help explain the procyclical behaviour of the labour wedge, which proved difficult to reconcile with standard macroeconomic and labour market models (see e.g. Shimer 2009 for a review of the literature on this topic). It is also consistent with the findings by Chari et al. (2007) who showed that labour wedges can account for $2 / 3$ of cyclical output fluctuations.

The introduction of differences in the degree of external finance dependence of exporters and domestic retailers such that $d_{E}>d_{D}$ leads to discrepancies in the equilibrium level of output and prices in the two sectors of the economy. Firstly, differences in working capital external financing requirements result in differences in 
the steady state levels of the external finance premia and the effective borrowing costs of exporters and domestic retailers. As long as in both sectors firms' default rates are positive, the external finance premia are also positive in both sectors. However, the exporting sector, which is characterised by greater cash flow constraints (and therefore higher $d_{X}$ ) is also characterised by lower steady-state output for any given realisation of aggregate shocks. Differences in the aggregate level of output in the two sectors of the economy lead to differences in the external finance premia as well as in the effective borrowing costs and prices which reduce the demand for exports relative to domestic sales and increase the discrepancy between the external finance premia in these two sectors even further.

Secondly, due to the fact that international trade is more dependent on external finance than domestic sales, the effective borrowing cost of exporters and, in consequence, also export prices are more sensitive to changes in macroeconomic conditions than the effective borrowing cost and prices of goods sold in the domestic economy. A decline in aggregate output in response to adverse macroeconomic shocks therefore leads to an increase in the relative price of exported to domestic goods and a decline in trade volume which exceeds that of output. An increase in aggregate output following positive shocks results in turn in the decline in the relative price of exports and an increase in the relative demand for these goods. As a result, the trade income elasticity is higher than one and the trade to GDP ratio is procyclical.

\section{Model Parametrisation}

In order to illustrate the transmission of shocks in the framework developed and examine the role of trade finance in the trade collapse of 2008-2009, the model is calibrated to match US data.

The inverse of the intertemporal elasticity of substitution in consumption, $\sigma$, is set equal to 2 , which is a value usually adopted in the international real business cycle literature. The inverse of the Frisch elasticity of labour supply, $\varphi$, is equal to 2, in line with estimates based on microeconomic data (Blundell and MaCurdy 1999). It is assumed that $\alpha=0.5$. The elasticity of substitution across varieties is set at $\theta=6$, which implies a pricing mark-up of $20 \%$ and is consistent with empirical estimates (Martins et al. 1996; Christiano et al. 2005).

The parameters determining the distribution of productivity levels among firms are set to match empirical evidence on firms' size distribution. If firms' productivity is distributed Pareto with shape parameter $k$, and the elasticity of substitution is given by $\theta$, then for the preference structure and production function assumed it follows that firms' sales revenues and employment are also distributed Pareto with shape parameter $k /(\theta-1)$. The parameter $k$ determining the dispersion of individual levels of productivity among firms is set equal to 6.25 , which implies that the shape parameter of the distribution of firms' size is equal to 1.25, as estimated by Axtell (2001). The value of the parameter $k$ adopted satisfies the condition $k>\theta-1$ which ensures that the distribution of firms' size has a finite mean. The lower bound for idiosyncratic productivity is normalised to one, $A_{\min }=1$. 
The fixed production costs are calibrated to match the average value of loan writeoffs in the corporate sector in the US. The value of the fixed costs adopted implies that in the steady state about $4 \%$ of the labour force is employed in setting-up firms and providing financial intermediation services. The costs of financial intermediation are assumed to be equal to $5 \%$ of the firm start-up costs. The fixed firm set-up costs and the financial intermediation costs are assumed to be the same for domestic retailers and exporters: $F_{D}=F_{E}$ and $G_{D}=G_{E}$.

The parameter $H_{X}$ which determines the cost of recovering collateral from a defaulting firm is set equal to 0.5 for domestic retailers as well as exporters, so that the fraction of the total value of the loans recovered by banks from bankrupted firms is in line with estimates of loan recovery rates. ${ }^{9}$ In the steady state, the probability of a bank's failure, $\varpi_{t}$, is assumed to be equal to $1 \%$.

As $80-90 \%$ of international trade relies on trade finance (Auboin 2009), the fraction of working capital which exporting firms need to finance externally is set to be equal to $d_{E}=0.8$. In turn, the external finance dependence of domestic retailers is determined in such a way that it reflects the differences in working capital financing requirements associated with domestic and international transactions.

One of the main reasons why international trade is more dependent on external finance than domestic sales is the fact that exporters face longer time lags between the production of goods and the receipt of sales revenues due to the additional time needed to transport goods abroad and to complete administrative procedures involved in international trade. These longer time lags result in greater working capital financing needs. Hummels (2001) estimates that the average shipment time in US trade is equal to 10.5 days. Djankov et al. (2010) find in a sample of 126 countries that on average 30 days pass between the moment when goods are ready to ship at the factory and their loading onto a ship. Similar delays are involved in transporting goods from a port to its final destination. For developed countries the average time required is about 13 days. These estimates indicate that in the US the time lag between receiving a purchase order and revenues from sales in international trade are nearly two months longer than the corresponding time lags in domestic sales. Raddatz (2006) uses data for US public manufacturing firms to provide a measure of the cash conversion cycle, which is the time elapsed between when a firm pays for its inputs and its receipt of payment for the goods it sells, for four digit ISIC industries in the US during 1980-1989. He finds that for the median firm in the median industry the cash conversion cycle is equal to 97 days. ${ }^{10}$ This estimate combined with the above statistics on international trade suggests that the time needed to obtain payment for a good sold in the domestic market is equal to about two-thirds of the time needed in the case of a good sold abroad. It is assumed that there are similar differences in firms' working capital external financing requirements and, as a result, the fraction of working capital financed externally for domestic retailers is set to be equal to

\footnotetext{
${ }^{9}$ The estimates of these rates range between 65\% in Asarnow and Edwards (1995), 56\% in Zhang (2009), $54 \%$ in Caselli et al. (2008), 46\% in Dúllmann and Trapp (2004), 38\% in Calabrese and Zenga (2010) and $35 \%$ in Thorburn (2000).

${ }^{10} \mathrm{~A}$ three-month period is also commonly assumed in the inventory literature (e.g. Christiano 1988).
} 

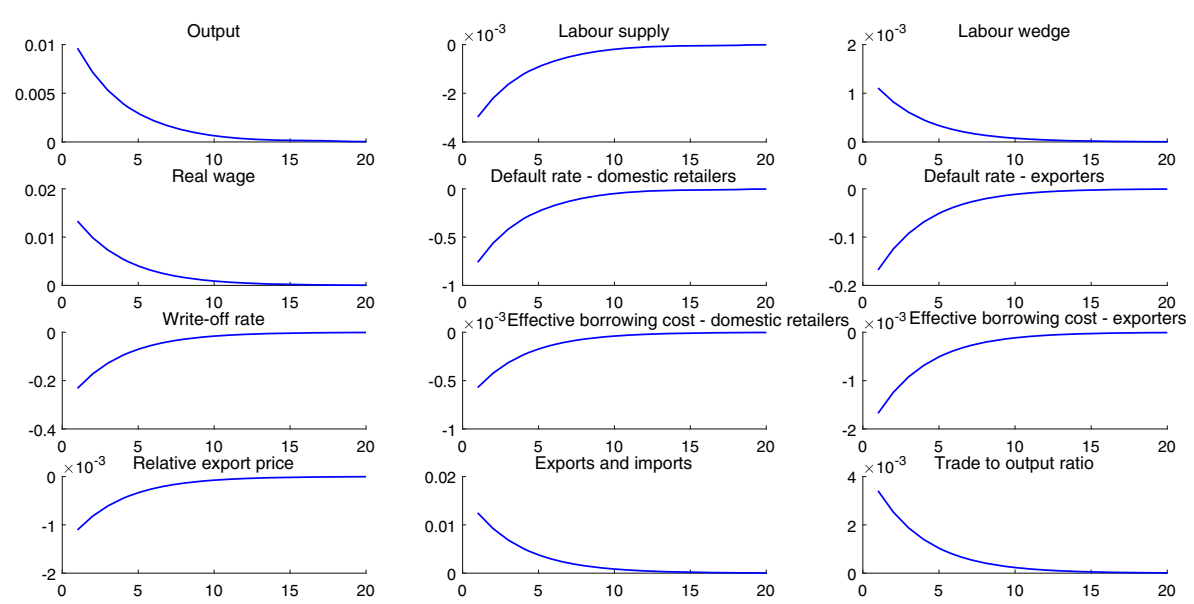

Fig. 5 Impulse responses to a positive global productivity shock

$d_{D}=0.5 .^{11}$ The parameters determining the degree of firms' external finance dependence adopted in this paper are consistent with survey evidence from the World Bank, which suggests that enterprises finance approximately 57 percent of their working capital requirements with external finance (Safavian and Wimpey 2007). ${ }^{12}$

\section{Quantitative Results}

In this section the calibrated model is tested empirically using Indirect Inference and it is applied to investigate the impact of financial markets' imperfections on the transmission of shocks in the economy and on international business cycle fluctuations.

\subsection{The Transmission of Shocks}

In the first part of the quantitative analysis impulse response functions are used to illustrate the impact of real and financial shocks on macroeconomic dynamics in the framework developed.

Figure 5 shows the effects of a positive symmetric one standard deviation productivity shock. ${ }^{13}$ An increase in aggregate productivity in both countries leads to an increase in output in the world economy. The percentage change in output is smaller than that of productivity due to the decline in labour supply following the shock, which

\footnotetext{
${ }^{11}$ The approach using industries' relative dependence on working capital to proxy their external finance dependence has also been adopted by Raddatz (2006).

${ }^{12}$ The values of all the model parameters adopted in the analysis are listed in Table 3 in Appendix A.3.

${ }^{13}$ The autocorrelation coefficients as well as the standard deviations of the structural shocks used in the calculation of the impulse response functions are estimated from the data and listed in Table 3 in Appendix A.3.
} 
results from the fact that in the model calibration used the income effect dominates the substitution effect, as the inverse of the intertemporal elasticity of substitution in consumption is assumed to be greater than one. The increase in output in the world economy raises firms' profits and leads to a decline in the number of firms which default on their debt and a decrease in the value of loans which are writtenoff as a result of firms' defaults. The fall in the riskiness of bank lending reduces the cost of external finance for firms. As exporting firms are more dependent on bank loans than domestic retailers, the relative price of exports decreases, which boosts demand for exported goods. As a result, the trade increase is 1.3 times greater than that of output. The elasticity of trade to GDP generated by the model is therefore considerably higher than the unitary elasticity implied by a standard real business cycle model which does not take financial frictions into account. The decline in the external finance premium following the shock also leads to an increase in the labour wedge, which would be constant in a standard model.

A positive demand shock has an impact on the trade to GDP ratio similar to that of a favourable productivity shock. Figure 6 illustrates the effects of a positive one standard deviation global demand shock which results from an exogenous increase in the utility of consumption for any given consumption level. The shock leads to an increase in output in the economy and a decline in firms' default rates, both in the domestic and in the exporting sectors, which in turn causes a decrease in the loan write-off rates. Banks face reduced credit risk which brings about lower costs of external finance for firms. As the decrease in firms' effective borrowing costs induces a decrease in the relative export price, the volume of international trade rises in relation to GDP - the change in real trade is 1.3 times larger than the change in real output. As in the case of the productivity shock, there is also an increase in the labour wedge.

In the framework developed, not only real shocks but also shocks originating in the financial markets have a significant impact on trade flows. Figure 7 shows the impact of a one standard deviation increase in the cost of loan financing for banks,
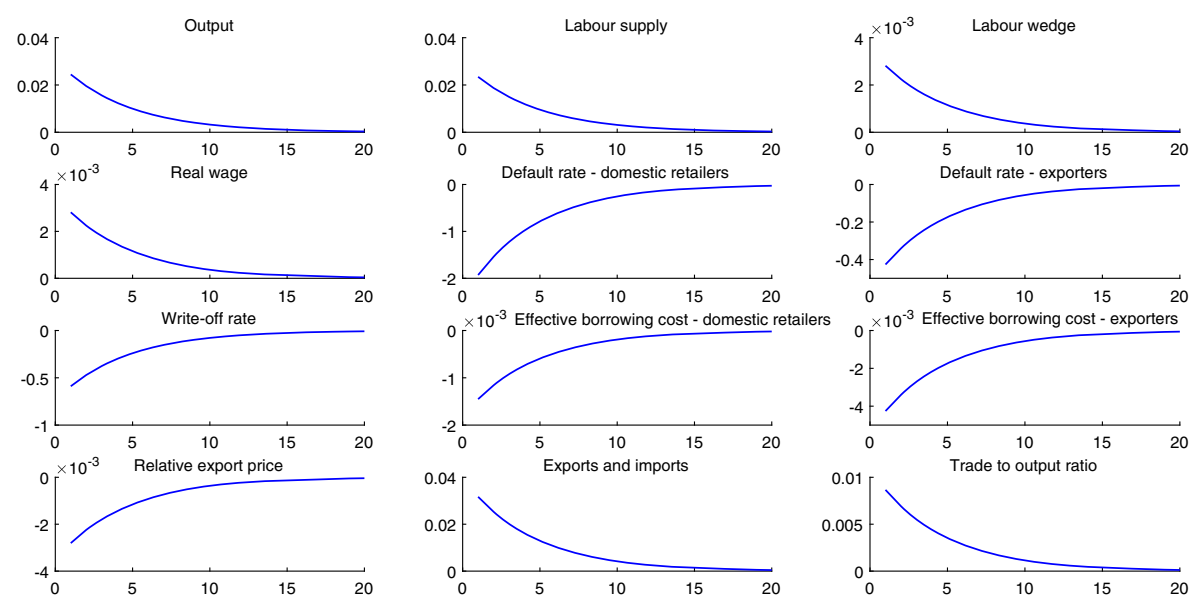

Fig. 6 Impulse responses to a positive global demand shock 

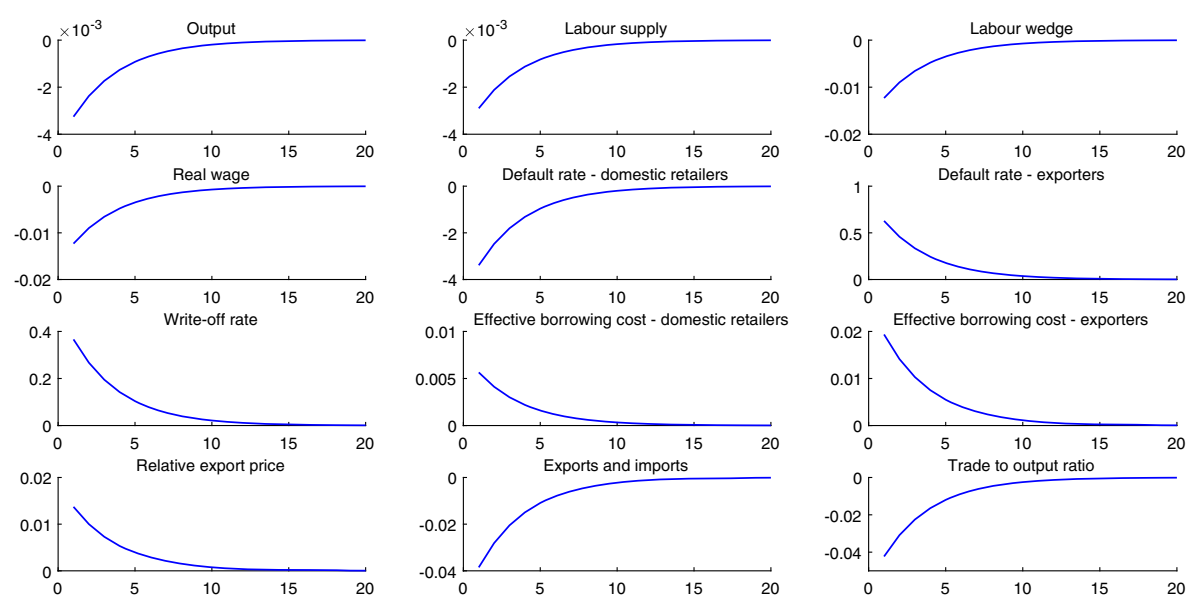

Fig. 7 Impulse responses to an increase in banks' cost of funds

which results from an exogenous one standard deviation decline in the probability of banks' survival. Higher cost of funds for banks translates into higher borrowing costs for firms. The shock therefore leads to an increase in firms' marginal costs and prices. As prices of exported and imported goods are more sensitive to changes in the cost of credit than prices of domestic goods, the shock results in a decrease in the share of foreign goods in households' consumption basket and a substantial decrease in the trade to GDP ratio.

\subsection{Model Evaluation by Indirect Inference}

The empirical performance of the model and its ability to account for the key features of the data is evaluated using the method of Indirect Inference proposed by Le et al. (2011) and explained in detail in Le et al. (2016). ${ }^{14}$ The test is rooted in the classical statistical inference framework and compares the properties of an auxiliary model estimated on data simulated from the structural model under investigation with the properties of an auxiliary model of the same specification estimated on actual data. If the structural model is correct then there should be a close match between the auxiliary model estimated from the simulated and actual data. While the auxiliary model can take various forms, a VAR is a natural choice. This is because, under suitable conditions, the state-space representation of a log-linearized DSGE model can be approximated by a finite-order reduced-form VAR. ${ }^{15}$ The Indirect Inference test then evaluates how close the restricted reduced-form VAR obtained from the structural model is to the unrestricted reduced-form VAR based on actual data.

The testing procedure is implemented in three steps. First, the structural shocks and innovations of the DSGE model are estimated conditional on data and model

\footnotetext{
${ }^{14}$ The Indirect Inference testing procedure can be carried out using the MATLAB toolbox available at http://www.patrickminford.net/Indirect/index.html

${ }^{15}$ See Giacomini (2013) for a review of the literature on the relationship between DSGE and VAR models.
} 
parameters. Second, the estimated innovations are bootstrapped and used to generate $\mathrm{N}$ independent samples of time series simulated from the model. Finally, each of these samples is used to estimate an auxiliary VAR model. An analogous auxiliary VAR is also estimated from the actual data. A Wald test is then applied to measure the distance between the estimates of the VAR coefficients obtained from the simulated data and the estimates of the VAR coefficients obtained from the actual data. The Wald statistic is given by:

$$
W S=\left(a_{T}-\overline{a_{S}}\left(\gamma_{0}\right)\right)^{\prime} W\left(\gamma_{0}\right)\left(a_{T}-\overline{a_{S}}\left(\gamma_{0}\right)\right)
$$

where $a_{T}$ is the vector of VAR coefficients estimated from actual data, $\overline{a_{S}}\left(\gamma_{0}\right)$ is the vector of mean VAR coefficients estimated from the simulated data, $W\left(\gamma_{0}\right)$ is the inverse of the variance-covariance matrix of the distribution of the vector of simulated estimates $a_{S}$ and $\gamma_{0}$ is the vector of parameters of the DSGE model under the null hypothesis that the model is a true representation of the data. Under the null hypothesis there should not be a statistically significant difference between $a_{T}$ and $\overline{a_{S}}\left(\gamma_{0}\right)$. The bootstrap distribution of the Wald statistic is estimated from the $\mathrm{N}$ bootstrap samples.

Le et al. (2016) show that in small samples the power of the Indirect Inference Wald test is considerable and larger than the power of a standard direct inference test based on the Likelihood Ratio. As the specification of the auxiliary model can freely be determined, another advantage of this evaluation method is that it offers flexibility in the focus of the test and allows it to be directed towards some key features of the data that the structural model aims to explain.

\subsubsection{Indirect Inference Test Results}

Applying the Indirect Inference test to the calibrated general equilibrium model developed in Section 3 demonstrated that the model is strongly supported by the data. The testing procedure was carried out as follows.

In the first step, the model's structural productivity, demand and financial shocks were estimated using quarterly US data for the log of real trade per capita, the log of real wage and the log of the ratio of the price of exported non-agricultural commodities to the price of all industrial commodities. ${ }^{16}$ As the data on export prices is only available from 1985 Q1, the analysis covered the time period from 1985 Q1 to 2017 Q4. One-sided HP filter was applied to all variables in order to remove the trend component from the data and to ensure stationarity of the time series used. ${ }^{17}$ In the analysis, the model's structural parameters were set at their calibrated values, as described in Section 5, while the three parameters determining the persistence of the structural shocks were estimated from the data. The structural shocks and innovations implied by the model and the data are shown in Fig. 8.

In the second step of the analysis, a non-parametric bootstrap with repeated draws by time vector was used to obtain 10000 samples of the innovations over the time

\footnotetext{
${ }^{16}$ Throughout the analysis, it was assumed that shocks are symmetric across countries.

${ }^{17}$ Using a linear trend to filter the data was not possible as it did not remove non-stationarity.
} 

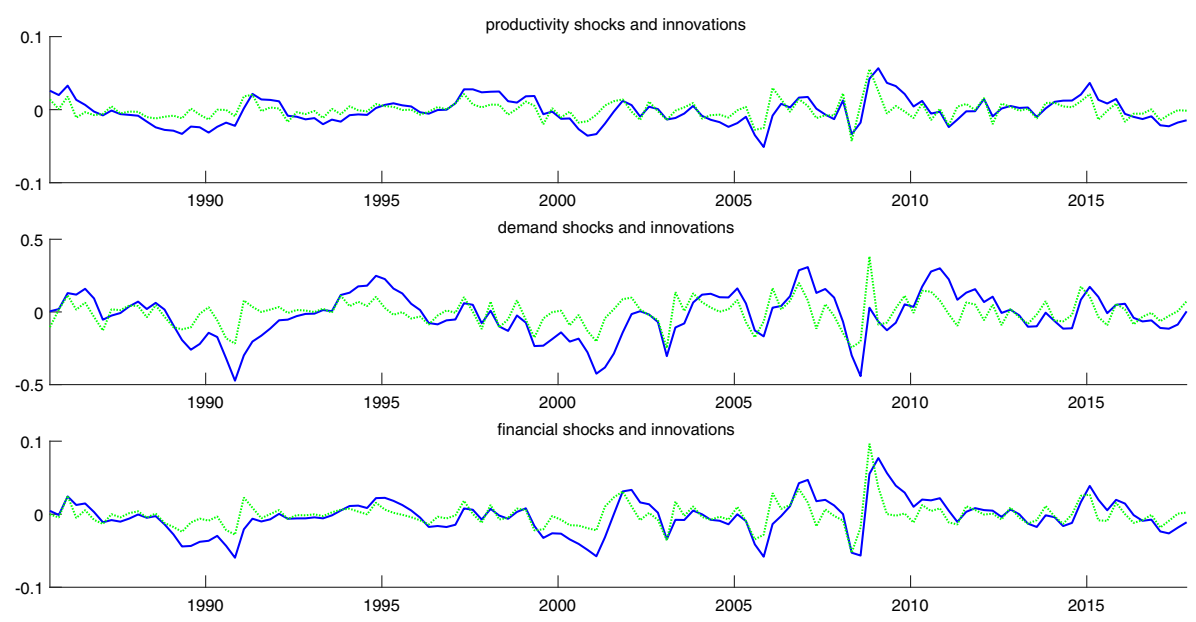

Fig. 8 The structural shocks and innovations estimated from the data. Note: the solid lines represent the structural shocks, while the dotted lines represent the innovations

period under consideration. They were then used, together with the calibrated structural model, to generate 10000 samples of model variables over the same time period.

Finally, the actual data and each of the simulated bootstrap samples were used to estimate a three-variable $\operatorname{VAR}(1)$ in real trade, real wages and the relative price of exported to domestic goods, and calculating the Wald statistic based on the nine VAR coefficients and the three variances of innovations. The null hypothesis that the structural model is correct could not be rejected at the $61 \%$ significance level.

The choice of the endogenous variables which were included in the auxiliary VAR model was motivated by the fact that international trade is the key variable which the model aims to explain, while the relative price of exports and real wage play a key role in the mechanism through which financial frictions affect the macroeconomy in the modelling framework developed. The relative price of exported to domestic goods captures the channel through which financial frictions and the changes in the cost of external finance for firms affect exporters and non-exporters differently and introduce a discrepancy in the response of output and international trade to shocks. As exporters are more dependent on external finance than domestic retailers, an increase in the cost of bank lending has a greater impact on the cost of exported goods as compared to domestic goods, which leads to an increase in the relative price of exported to domestic goods and a decline in the relative demand for these goods. Furthermore, in the model, financial frictions play an important role in the determination of real wages by generating a labour wedge and therefore, if the model is correct, the significant impact of financial shocks on wages should be reflected in the data.

The results from the Indirect Inference test are robust to using an auxiliary VAR(1) and actual data for other combinations of the endogenous variables. Using the combination of output, real wages and the relative price of exports, the combination of consumption, the relative price of exports and real wage and the combination of trade, 
Table 1 Wald test rejection rates for a 3-variable VAR(1)

\begin{tabular}{lllll}
\hline $\begin{array}{l}\text { Percentage change in model parameters } \\
\text { Probability of rejection of the misspecified model }\end{array}$ & $\begin{array}{llll}0.4 \\
11.5 \%\end{array}$ & $21.5 \%$ & $91.5 \%$ & $100 \%$ \\
\hline
\end{tabular}

real wage and the loan write-off rate, all result in the model not being rejected by the data at the significance level of $9 \%$ or higher. ${ }^{18}$

While the Indirect Inference test was carried out using a VAR as the auxiliary model, asymptotically the test is equivalent to using Impulse Response Functions as the descriptor of the data. Furtheremore, Minford et al. (2016) show that in small samples there is no significant difference in the power of the test based on a VAR and on Impulse Response Functions.

\subsubsection{The Power of the Wald Test}

The power of the Wald test was examined by carrying out the Indirect Inference testing procedure on a number of False models with an increasing degree of numerical misspecification and checking what percentage of them is rejected by the data generated from the True model. The Monte Carlo experiment was conducted as follows. First, the calibrated structural model was treated as the True model of the economy and used to generate 500 data samples using normally distributed innovations with standard deviations corresponding to those obtained from the data. Second, a number of False models were constructed by changing the structural model parameters upwards and downwards in an alternating manner so that they are a certain percentage higher or lower than their true values. ${ }^{19}$ Each of these False models was tested against each of the 500 simulated 'true' data samples with the use of the Indirect Inference testing procedure based on 1000 bootstrap data samples generated from the False model. It was then examined for how many of the data samples the False model was rejected at the $5 \%$ significance level. The rates at which the False models were rejected by the data are presented in Table 1 .

The results show that the Indirect Inference test has good power against poor parameter values and the power increases considerably with the degree of model misspecification. Changing the model parameters by 1 percent results in the Wald test rejecting the False model with $100 \%$ probability. This is to some extent due to the fact that in a model with heterogenous firms and cash flow constraints the steady state is a highly non-linear function of the model parameters and is very sensitive to their changes. For example, altering the model parameters by $1 \%$ leads to an increase in the steady state value of the percentage of domestic retailers who default on their

\footnotetext{
${ }^{18}$ The results of the Indirect Inference tests remain robust when additional structural shocks are introduced into the model: a shock to the elasticity of substitution between varieties resulting in a time-varying markup, shocks to the loan recovery costs, shocks to the financial intermediation fee and shocks to the working capital financing needs. The details of the robustness analysis are described in Appendix A.4.

${ }^{19}$ The changed parameters included the error autocorrelation coefficients. However, in order to ensure that the steady state exists and that it has a plausible economic interpretation, the parameter $k$, determining the dispersion of the levels of productivity among firms was kept constant.
} 
Table 2 Variance decomposition

\begin{tabular}{|c|c|c|c|}
\hline Variable & $z$ & $u$ & $b$ \\
\hline Trade & 5.50 & 44.09 & 50.41 \\
\hline Output & 10.96 & 87.84 & 1.20 \\
\hline Consumption & 10.96 & 87.84 & 1.20 \\
\hline Consumption of domestic goods & 2.47 & 19.78 & 77.75 \\
\hline Consumption of foreign goods & 4.82 & 38.63 & 56.55 \\
\hline Wage & 53.28 & 2.96 & 43.76 \\
\hline Labour supply & 1.27 & 97.58 & 1.15 \\
\hline Labour wedge & 0.78 & 6.28 & 92.93 \\
\hline Relative price of exported to domestic goods & 0.64 & 5.10 & 94.26 \\
\hline Price of domestic goods & 0.64 & 5.10 & 94.26 \\
\hline Price of exported goods & 0.64 & 5.10 & 94.26 \\
\hline Default rate - domestic retailers & 3.55 & 28.48 & 67.95 \\
\hline Default rate - exporters & 4.45 & 35.69 & 59.86 \\
\hline Loan write-off rate & 8.76 & 70.24 & 20.99 \\
\hline Borrowing cost - domestic retailers & 0.97 & 7.79 & 91.24 \\
\hline Borrowing cost - exporters & 0.73 & 5.84 & 93.43 \\
\hline Effective borrowing cost - domestic retailers & 0.97 & 7.79 & 91.24 \\
\hline Effective borrowing cost - exporters & 0.73 & 5.84 & 93.43 \\
\hline Average productivity - defaulting domestic retailers & 3.55 & 28.48 & 67.97 \\
\hline Average productivity - non-defaulting domestic retailers & 3.55 & 28.48 & 67.97 \\
\hline Average productivity - defaulting exporters & 4.45 & 35.69 & 59.86 \\
\hline Average productivity - non-defaulting exporters & 4.45 & 35.69 & 59.86 \\
\hline
\end{tabular}

$z, u$ and $b$ denote the productivity, demand and financial shocks, respectively

debt from $1 \%$ to $5 \%$, which has significant implications for borrowing costs and other steady state variables as well as for the dynamic properties of the model.

\subsection{International Trade over the Business Cycle}

The variance decomposition presented in Table 2 demonstrates that financial shocks significantly contribute to business cycle fluctuations. ${ }^{20}$ They are the most important determinant of changes in the cost of external finance for firms and the relative price of exports to domestic goods. In consequence, they play a key role in the determination of international trade, explaining $50 \%$ of its variance, with demand and productivity shocks contributing $44 \%$ and $6 \%$ respectively. Furthermore, as financial shocks are the most important source of movements in the labour wedge, they also

\footnotetext{
${ }^{20}$ The variance decomposition was obtained based on the assumption that the standard deviations of innovations are at the levels estimated from the data.
} 


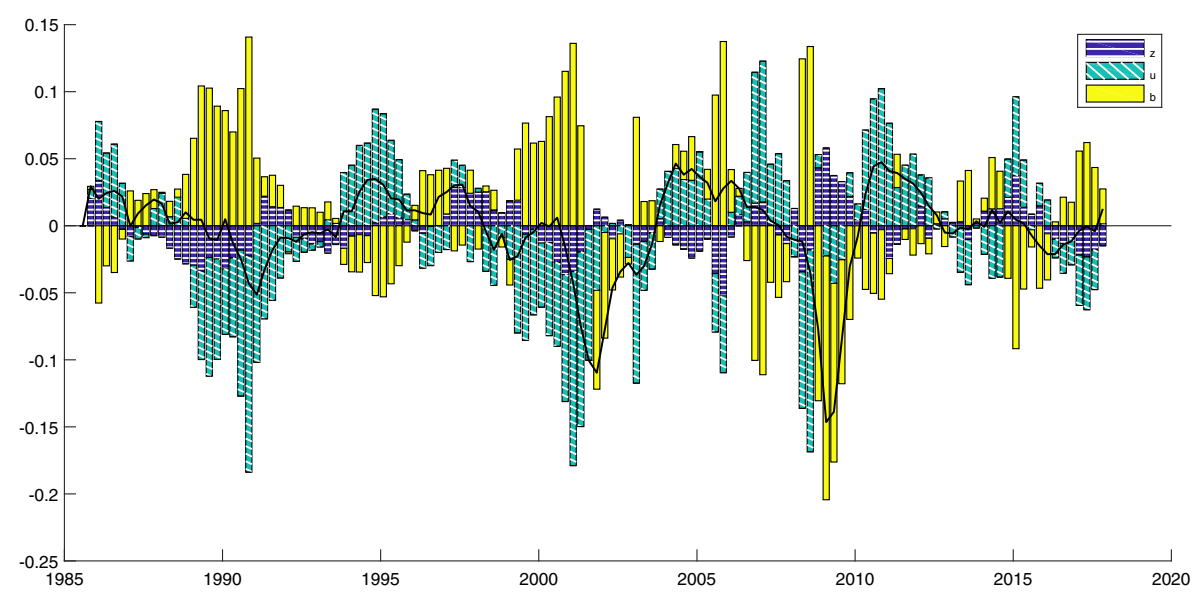

Fig. 9 The contribution of structural shocks to the evolution of international trade. Note: the bars represent the impact of the productivity $(z)$, demand $(u)$ and financial $(b)$ shocks on international trade, while the solid line represents the combined impact of all the shocks

have a significant impact on wages and contribute to $44 \%$ of their variation, while productivity shocks explain a further 53\%. Financial shocks are far less important in the determination of output and consumption, which are mainly driven by demand and productivity shocks. Similarly, they play very little role in the determination of labour supply, which mostly alters due to changes in demand.

Historical decomposition demonstrates that financial factors played an important role in the fluctuations of international trade during the period from 1985 to 2017

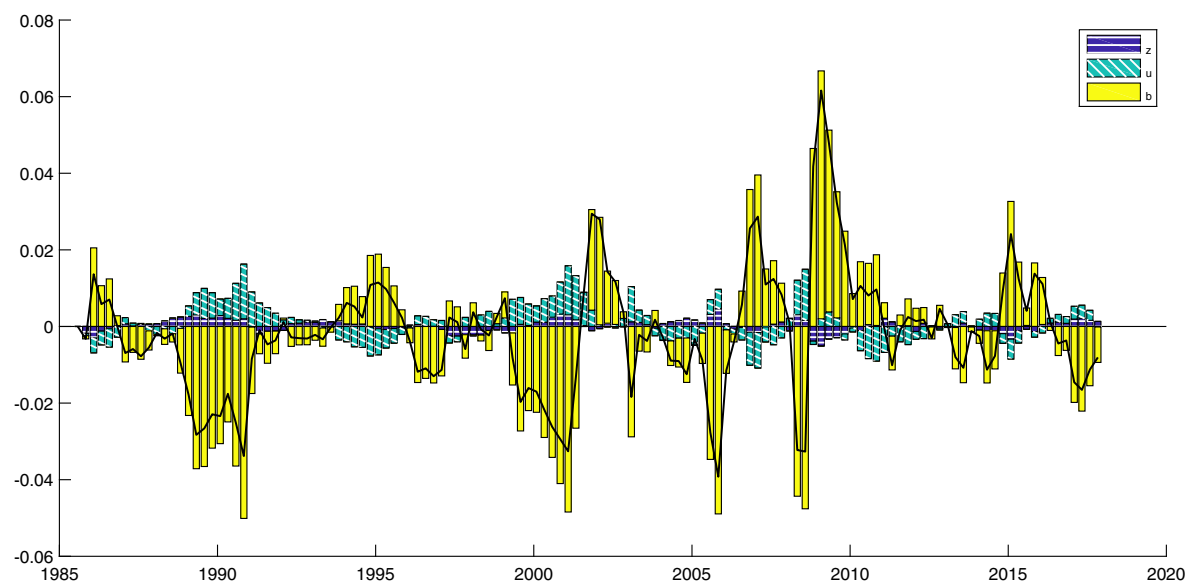

Fig. 10 The contribution of structural shocks to the evolution of the relative export price. Note: the bars represent the impact of the productivity $(z)$, demand $(u)$ and financial $(b)$ shocks on the relative export price, while the solid line represents the combined impact of all the shocks 


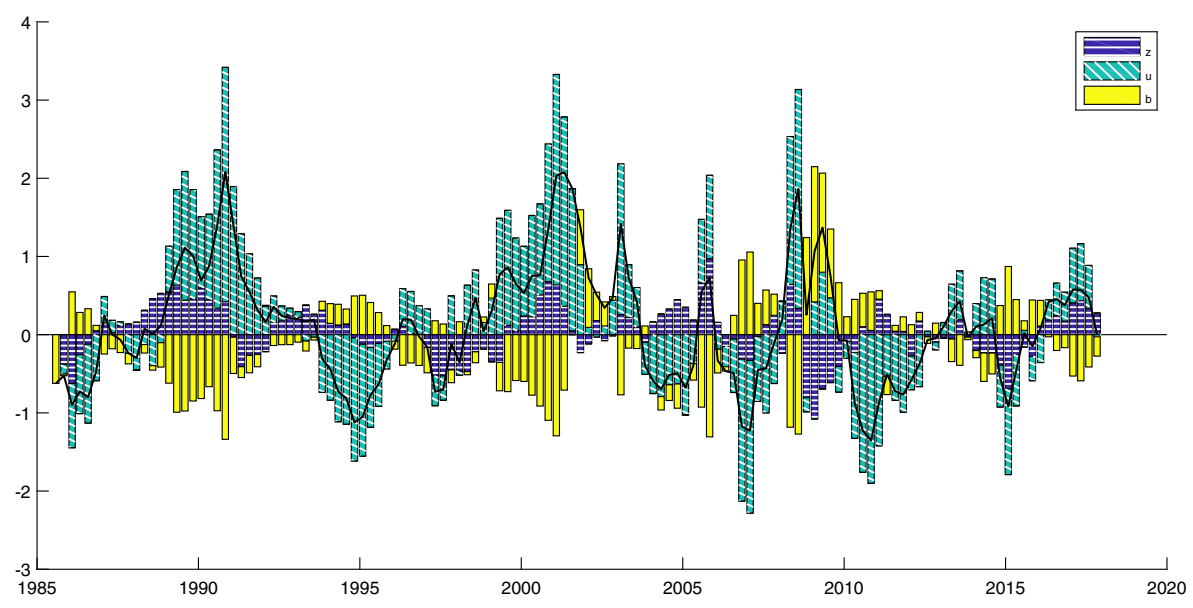

Fig. 11 The contribution of structural shocks to the evolution of the loan write-off rate. Note: the bars represent the impact of the productivity $(z)$, demand $(u)$ and financial $(b)$ shocks on the loan write-off rate, while the solid line represents the combined impact of all the shocks

and, in particular, during the global financial crisis. Figures 9, 10, 11 and 12 as well as Figs. 13-17 in Appendix A.5 show the contribution of each of the structural shocks to the evolution of the key model variables over the sample period.

As shown in Fig. 9, the great trade collapse in 2008-2009 can be attributed to a combination of a negative demand shock and a financial shock raising banks' cost of funds, with the latter playing a dominant role. An increase in banks' financing

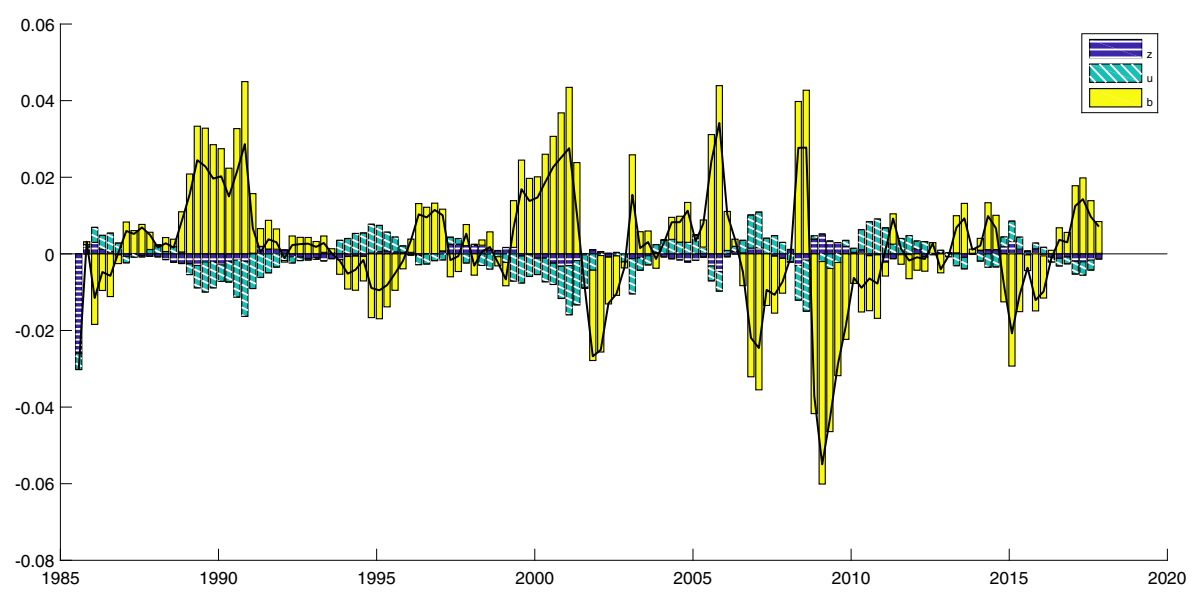

Fig. 12 The contribution of structural shocks to the evolution of the labour wedge. Note: the bars represent the impact of the productivity $(z)$, demand $(u)$ and financial $(b)$ shocks on the labour wedge, while the solid line represents the combined impact of all the shocks 
costs, driven by an increased risk in the financial sector, together with a negative shock to aggregate demand resulted in higher cost of external finance for firms (see Figs. 13 and 14 in Appendix A.5). As international trade is more dependent on external finance than domestic transactions, the effective borrowing cost increased more for exporters than non-exporters, exerting an upward pressure on the relative price of exported to domestic goods. Figure 10 confirms that the sharp increase in the relative price of exports observed at the time of the crisis was mainly driven by financial shocks. The increase in the relative price of exported to domestic goods significantly contributed to the fall in trade during the crisis period, which considerable exceeded the decline in output.

Financial frictions and the differences in external financing requirements associated with domestic and international transactions played a key role in the determination of the dynamics of trade over the crisis period. In their absence the relative price of exported to domestic goods would be constant over time and the percentage changes in international trade would be the same as the percentage changes in output.

The model is able to capture the behaviour of other key macroeconomic developments during the financial crisis and over the sample period in general. As shown in Figs. 11 and 12, it implies a significant increase in the loan write-off rates (caused by increased borrowing cost and worsening demand conditions) and a sharp deterioration in the labour wedge (driven mainly by financial shocks) which in its size and direction closely match those observed in the data. ${ }^{21}$ As shown in Figs. 15 and 16 in Appendix A.5, fluctuations in output and labour supply derived from the model and the estimated structural shocks are also broadly in line with the actual time series during the period covered by the analysis.

The results indicating significant contribution of financial factors to the decline in trade during the financial crisis are in line with the findings of Chor and Manova (2012) who estimate that between October 2008 and April 2009 international trade flows would have been higher by $30 \%$, if government policies to lower the cost of lending had a more immediate effect. The model developed in this paper provides an explanation of the great trade collapse complementary to those implied by recently proposed models accounting for vertical production linkages and the composition of international trade (e.g. Bems et al. 2010; Eaton et al. 2016). Moreover, the model accounts for the changes in the relative prices of exported to domestic goods and in the labour wedge during the crisis which are not explained in other models.

\section{Conclusions}

The paper introduces working capital financing constraints into an open-economy general equilibrium model with heterogeneous firms. It then investigates the impact

\footnotetext{
${ }^{21}$ Between 2008 Q2 and 2009 Q2 there was a three-fold increase in the write-off rate on commercial and industrial loans in the US, from $0.8 \%$ to $2.4 \%$. During the same period the labour wedge in the US declined by nearly a tenth (Kobayashi 2011).
} 
of financial frictions on business cycle fluctuations and, in particular, the dynamics of international trade. The role of credit market imperfections in the great trade collapse of 2008-2009 is also examined.

The paper suggests a novel mechanism generating a countercyclical external finance premium, which is the result of the presence of irreversible fixed costs of production, firms' idiosyncratic risk and cash flow constraints. Changes in macroeconomic conditions affect the riskiness and cost of bank lending, which in turn leads to changes in firms' marginal costs and the labour wedge. Due to differences in the working capital financing needs of exporters and domestic retailers, the relative price of domestic and imported goods and the relative demand for these goods also change. As firms selling their goods abroad have longer cash conversion cycles and are more dependent on external finance than firms serving the domestic market, international trade is more sensitive to macroeconomic shocks than domestic sales.

The study shows that financial frictions significantly contribute to the transmission of shocks in an open economy. Differences in firms' external financing requirements associated with international and domestic transactions help to explain the strong procyclicality of the trade to GDP ratio observed in the data. Following shocks to demand and productivity, the elasticity of trade with respect to output generated by the structural model developed in this paper is equal to 1.3. Shocks to the cost of credit originating in financial markets have an even stronger impact on the relative volatility of international trade and output. The analysis demonstrates that credit market imperfections played an important role in the determination of international trade flows during the global financial crisis. The mechanism through which financial frictions affect the economy in the modelling framework proposed found considerable support in the data. The model is able to account for the simultaneous collapse in international trade, significant increase in the loan write-off rates, a sharp fall in the labour wedge and a considerable increase in the prices of exports relative to domestic goods observed during the crisis period. Formal test based on Indirect Inference confirmed that the model is able to explain the key features of the data well.

\footnotetext{
Acknowledgments I am extremely grateful to the referee who waived anonymity, Patrick Minford, for his extensive and invaluable comments and advice. I would also like to thank Sean Holly, Giancarlo Corsetti, Philip Lane, Fabio Ghironi, Michael B. Devereux, Oliver de Groot, Marco Maffezzoli, Sergejs Saksonovs as well as the participants of the Italian Trade Study Group conference on 'International Trade, Finance and Migration', the Spring Meeting of Young Economists, the ZEW Summer Macroeconomics Workshop on International Business Cycles, the International Economics Seminar at the University of Munich, the RES Annual Conference and the Cambridge Finance Workshop for helpful discussions, comments and suggestions. This research was funded by the Economic and Social Research Council, UK, and Corpus Christi College, Cambridge, UK.
}

Open Access This article is distributed under the terms of the Creative Commons Attribution 4.0 International License (http://creativecommons.org/licenses/by/4.0/), which permits unrestricted use, distribution, and reproduction in any medium, provided you give appropriate credit to the original author(s) and the source, provide a link to the Creative Commons license, and indicate if changes were made. 


\section{Appendix A}

\section{A.1 Flexible Price Equilibrium}

This section lists the Home economy equilibrium conditions of the model.

Risk-sharing condition:

$$
\left(\frac{C_{t}}{C_{t}^{*}}\right)^{\sigma} \frac{U_{t}^{*}}{U_{t}}=\frac{S_{t} P_{t}^{*}}{P_{t}}
$$

Intratemporal labour equation:

$$
\frac{W_{t}}{P_{t}}=\frac{C_{t}^{\sigma} L_{t}^{\varphi}}{U_{t}}
$$

Consumption aggregator:

$$
C_{t}=\left(\alpha^{\frac{1}{\theta}} C_{D, t}^{\frac{\theta-1}{\theta}}+(1-\alpha)^{\frac{1}{\theta_{t}}} C_{I, t}^{\frac{\theta-1}{\theta}}\right)^{\frac{\theta}{\theta-1}}
$$

Aggregate consumption - domestic retailers:

$$
C_{D, t}=\alpha\left(\frac{P_{D, t}}{P_{t}}\right)^{-\theta} C_{t}
$$

Aggregate consumption - exporters:

$$
C_{E, t}=(1-\alpha)\left(\frac{P_{I, t}^{*}}{P_{t}^{*}}\right)^{-\theta} C_{t}^{*}
$$

Price index - domestic retailers:

$$
P_{D, t}=\frac{\theta}{\theta-1} \frac{W_{t}}{Z_{t} A_{D A}} \widetilde{R}_{D, t}
$$

Price index - exporters:

$$
P_{I, t}^{*}=\frac{1}{S_{t}} \frac{\theta}{\theta-1} \frac{W_{t}}{Z_{t} A_{E A}} \widetilde{R}_{E, t}
$$

Effective borrowing cost - domestic retailers:

$$
\widetilde{R}_{D, t}=\left(1-d_{D}\right)+d_{D} R_{D, t}
$$

Effective borrowing cost - exporters:

$$
\widetilde{R}_{E, t}=\left(1-d_{E}\right)+d_{E} R_{E, t}
$$

Production function - domestic retailers:

$$
Y_{D, t}=Z_{t} A_{D A} L_{D, t}
$$


Production function - exporters:

$$
Y_{E, t}=Z_{t} A_{E A} L_{E, t}
$$

Labour market equilibrium condition:

$$
L_{t}=L_{D, t}+L_{E, t}+\frac{1}{Z_{t}}\left(F_{D}+G_{D}+F_{E}+G_{E}\right)
$$

Resource constraints - domestic retailers:

$$
Y_{D, t}=C_{D, t}
$$

Resource constraints - exporters:

$$
Y_{E, t}=C_{I, t}^{*}
$$

Average productivity - all firms:

$$
A_{D A}=A_{E A}=\left[\frac{k}{k-(\theta-1)}\right]^{\frac{1}{\theta-1}} A_{\min }=v A_{\min }
$$

where

$$
v=\left[\frac{k}{k-(\theta-1)}\right]^{\frac{1}{\theta-1}}
$$

Average productivity - non-defaulting domestic retailers:

$$
A_{D H, t}=\left[\frac{k}{k-(\theta-1)}\right]^{\frac{1}{\theta-1}} \bar{A}_{D, t}=v \bar{A}_{D, t}
$$

Average productivity - defaulting domestic retailers:

$$
A_{D L, t}=v A_{\min }\left[\frac{1}{N_{D, t}}-\frac{1}{N_{D, t}}\left(1-N_{D, t}\right)^{\frac{k-\theta+1}{k}}\right]^{\frac{1}{\theta-1}}
$$

Average productivity - non-defaulting exporters:

$$
A_{E H, t}=\left[\frac{k}{k-(\theta-1)}\right]^{\frac{1}{\theta-1}} \bar{A}_{E, t}=v \bar{A}_{E, t}
$$

Average productivity - defaulting exporters:

$$
A_{E L, t}=v\left[\frac{1}{N_{E, t}} A_{\min }^{\theta-1}-\frac{\left(1-N_{E, t}\right)}{N_{E, t}}\left(\bar{A}_{E, t}\right)^{\theta-1}\right]^{\frac{1}{\theta-1}}
$$

Threshold level of productivity - domestic retailers:

$$
\frac{\mu-1}{\mu} \alpha\left(\mu \frac{W_{t}}{Z_{t} \bar{A}_{D, t}} \widetilde{R}_{D, t}\right)^{1-\theta} C_{t} P_{t}^{\theta}=\frac{W_{t}}{Z_{t}}\left(F_{D}+G_{D}\right) R_{D, t}
$$

where

$$
\mu=\frac{\theta}{\theta-1}
$$


Threshold level of productivity - exporters:

$$
\frac{\mu-1}{\mu}(1-\alpha)\left(\mu \frac{W_{t}}{Z_{t} \bar{A}_{E, t}} \widetilde{R}_{E, t}\right)^{1-\theta}\left(S_{t} P_{t}^{*}\right)^{\theta} C_{t}^{*}=\frac{W_{t}}{Z_{t}}\left(F_{E}+G_{E}\right) R_{E, t}
$$

Probability of default - domestic retailers:

$$
N_{D, t}=F\left(\bar{A}_{D, t}\right)=1-\left(\frac{A_{\min }}{\bar{A}_{D, t}}\right)^{k}
$$

Probability of default - exporters:

$$
N_{E, t}=F\left(\bar{A}_{E, t}\right)=1-\left(\frac{A_{\min }}{\bar{A}_{E, t}}\right)^{k}
$$

Participation constraint - domestic retailers:

$$
\begin{aligned}
& \left(1-N_{D, t}\right)\left[d_{D} \alpha\left(\mu \widetilde{R}_{D, t}\right)^{-\theta}\left(\frac{W_{t}}{Z_{t} A_{D H, t}}\right)^{1-\theta} P_{t}^{\theta} C_{t}+\frac{W_{t}}{Z_{t}}\left(F_{D}+G_{D}\right)\right] R_{D, t} \\
& +\left(1-H_{D}\right) N_{D, t}\left[\alpha\left(\mu \frac{W_{t}}{Z_{t} A_{D L, t}} \widetilde{R}_{D, t}\right)^{1-\theta} P_{t}^{\theta} C_{t}\left(1-\frac{1-d_{D}}{\mu_{t} \widetilde{R}_{D, t}}\right)\right] \\
= & M_{t}\left[d_{D} \alpha\left(\mu_{t} \widetilde{R}_{D, t}\right)^{-\theta}\left(\frac{W_{t}}{Z_{t} A_{D A}}\right)^{1-\theta} P_{t}^{\theta} C_{t}+\frac{W_{t}}{Z_{t}}\left(F_{D}+G_{D}\right)\right]
\end{aligned}
$$

Participation constraint - exporters:

$$
\begin{aligned}
& \left(1-N_{E, t}\right)\left[d_{E}(1-\alpha)\left(\mu \widetilde{R}_{E, t}\right)^{-\theta}\left(\frac{W_{t}}{Z_{t} A_{E H, t}}\right)^{1-\theta}\left(S_{t} P_{t}^{*}\right)^{\theta} C_{t}^{*}+\frac{W_{t}}{Z_{t}}\left(F_{E}+G_{E}\right)\right] R_{E, t} \\
& +\left(1-H_{E}\right) N_{E, t}\left[(1-\alpha)\left(\mu \frac{W_{t}}{Z_{t} A_{E L, t}} \widetilde{R}_{E, t}\right)^{1-\theta}\left(S_{t} P_{t}^{*}\right)^{\theta} C_{t}^{*}\left(1-\frac{1-d_{E}}{\mu \widetilde{R}_{E, t}}\right)\right] \\
= & M_{t}\left[d_{E}(1-\alpha)\left(\mu \widetilde{R}_{E, t}\right)^{-\theta}\left(\frac{W_{t}}{Z_{t} A_{E A}}\right)^{1-\theta}\left(S_{t} P_{t}^{*}\right)^{\theta} C_{t}^{*}+\frac{W_{t}}{Z_{t}}\left(F_{E}+G_{E}\right)\right]
\end{aligned}
$$

Normalisation:

$$
\begin{aligned}
& P_{t}=1 \\
& S_{t}=1
\end{aligned}
$$

The complete model consists of all the above listed equilibrium conditions for the Home economy and the Foreign economy equivalents of the equilibrium conditions: (34)-(59).

\section{A.2 Log-linearized Equilibrium Conditions}

This section lists the log-linearized Home economy equilibrium conditions of the model. 
Risk-sharing condition:

$$
\sigma \widehat{c}_{t}-\sigma \widehat{c}_{t}^{*}+\widehat{u}_{t}^{*}-\widehat{u}_{t}=\widehat{s}_{t}+\widehat{p}_{t}^{*}-\widehat{p}_{t}
$$

Intratemporal labour equation:

$$
\widehat{w}_{t}-\widehat{p}_{t}=\sigma \widehat{c_{t}}+\varphi \widehat{l}_{t}-\widehat{u}_{t}
$$

Consumption aggregator:

$$
\widehat{c}_{t}=\frac{\theta-1}{\theta} \alpha^{\frac{1}{\theta}}\left(\frac{C_{D}}{C}\right)^{\frac{\theta-1}{\theta}} \widehat{c}_{D, t}+\frac{\theta-1}{\theta}(1-\alpha)^{\frac{1}{\theta}}\left(\frac{C_{I}}{C}\right)^{\frac{\theta-1}{\theta}} \widehat{c}_{I, t}
$$

Aggregate consumption - domestic retailers:

$$
\widehat{c}_{D, t}=-\theta \widehat{p}_{D, t}+\theta \widehat{p}_{t}+\widehat{c}_{t}
$$

Aggregate consumption - exporters:

$$
\widehat{c}_{E, t}=-\theta \widehat{p}_{I, t}^{*}+\theta \widehat{p}_{t}^{*}+\widehat{c}_{t}^{*}
$$

Price index - domestic retailers:

$$
\widehat{p}_{D, t}=\widehat{w}_{t}+\widehat{\widetilde{r}}_{D, t}-\widehat{z}_{t}
$$

Price index - exporters:

$$
\widehat{p}_{I, t}^{*}=\widehat{w}_{t}+\widehat{\widetilde{r}}_{E, t}-\widehat{z}_{t}-\widehat{s}_{t}
$$

Effective borrowing cost - domestic retailers:

$$
\widehat{\widetilde{r}}_{D, t}=\frac{d_{D} R_{D}}{\widetilde{R}_{D}} \widehat{r}_{D, t}
$$

Effective borrowing cost - exporters:

$$
\widehat{\widetilde{r}}_{E, t}=\frac{d_{E} R_{E}}{\widetilde{R}_{E}} \widehat{r}_{E, t}
$$

Production function - domestic retailers:

$$
\widehat{y}_{D, t}=\widehat{z}_{t}+\widehat{l}_{D, t}
$$

Production function - exporters:

$$
\widehat{y}_{E, t}=\widehat{z}_{t}+\widehat{l}_{E, t}
$$


Labour market equilibrium condition:

$$
\widehat{l}_{t}=\frac{L_{D}}{L} \widehat{l}_{D, t}+\frac{L_{E}}{L} \widehat{l}_{E, t}-\frac{1}{L Z}\left(F_{D}+G_{D}+F_{E}+G_{E}\right) \widehat{z}_{t}
$$

Resource constraints - domestic retailers:

$$
\widehat{y}_{D, t}=\widehat{c}_{D, t}
$$

Resource constraints - exporters:

$$
\widehat{y}_{E, t}=\widehat{c}_{I, t}^{*}
$$

Average productivity - non-defaulting domestic retailers:

$$
\widehat{a}_{D H, t}=\widehat{\bar{a}}_{D, t}
$$

Average productivity - defaulting domestic retailers:

$\widehat{a}_{D L, t}=\frac{v}{\theta-1} A_{\min }\left(A_{D L}\right)^{1-\theta} \frac{1}{N_{D}}\left(\frac{k-\theta+1}{k}\left(1-N_{D}\right)^{\frac{1-\theta}{k}} N_{D}+\left(1-N_{D}\right)^{\frac{k+1-\theta}{k}}-1\right) \widehat{n}_{D, t}$

Average productivity - non-defaulting exporters:

$$
\widehat{a}_{E H, t}=\widehat{\bar{a}}_{E, t}
$$

Average productivity - defaulting exporters:

$$
\widehat{a}_{E L, t}=\frac{v}{\theta-1} A_{\min }\left(A_{E L}\right)^{1-\theta} \frac{1}{N_{E}}\left(\frac{k-\theta+1}{k}\left(1-N_{E}\right)^{\frac{1-\theta}{k}} N_{E}+\left(1-N_{E}\right)^{\frac{k-\theta+1}{k}}-1\right) \widehat{n}_{E, t}
$$

Threshold level of productivity - domestic retailers:

$$
\left.(1-\theta) \widehat{\widetilde{r}}_{D, t}-\widehat{\bar{a}}_{D, t}\right)+\widehat{c}_{t}+\theta \widehat{p}_{t}=\theta \widehat{w}_{t}+\widehat{r}_{D, t}-\theta \widehat{z}_{t}
$$

Threshold level of productivity - exporters:

$$
(1-\theta)\left(\widehat{\widetilde{r}}_{E, t}-\widehat{\bar{a}}_{E, t}\right)+\widehat{c}_{t}^{*}+\theta \widehat{p}_{t}^{*}+\theta \widehat{s}_{t}=\theta \widehat{w}_{t}+\widehat{r}_{E, t}-\theta \widehat{z}_{t}
$$

Probability of default - domestic retailers:

$$
\widehat{n}_{D, t}=\frac{k\left(\frac{A_{\min }}{\bar{A}_{D}}\right)^{k}}{N_{D}} \widehat{\bar{a}}_{D, t}
$$


Probability of default - exporters:

$$
\widehat{n}_{E, t}=\frac{k\left(\frac{A_{\min }}{\bar{A}_{E}}\right)^{k}}{N_{E}} \widehat{\bar{a}}_{E, t}
$$

Participation constraint - domestic retailers:

$$
\begin{aligned}
& \left(1-N_{D}\right) R_{D}\left[d_{D} \alpha\left(\mu \widetilde{R}_{D}\right)^{-\theta}\left(\frac{W}{Z A_{D H}}\right)^{1-\theta} P^{\theta} C+\frac{W}{Z}\left(F_{D}+G_{D}\right)\right] \widehat{r}_{D, t} \\
& +N_{D} \alpha\left(\mu \widetilde{R}_{D}\right)^{-\theta}\left(\frac{W}{Z}\right)^{1-\theta} P^{\theta} C\left(H_{D}\left(A_{D L}\right)^{\theta-1}\left(\mu \widetilde{R}_{D}-\left(1-d_{D}\right)\right)-R_{D} d_{D}\left(A_{D L}\right)^{\theta-1}\right) \widehat{n}_{D, t} \\
& -N_{D} R_{D} \frac{W}{Z}\left(F_{D}+G_{D}\right) \widehat{n}_{D, t} \\
& +(1-\theta) \alpha\left(\mu \widetilde{R}_{D}\right)^{-\theta}\left(\frac{W}{Z}\right)^{1-\theta} P^{\theta} C\left[1-N_{D}\right] R_{D} d_{D}\left(A_{D H}\right)^{\theta-1} \widehat{w}_{t} \\
& +(1-\theta) \alpha\left(\mu \widetilde{R}_{D}\right)^{-\theta}\left(\frac{W}{Z}\right)^{1-\theta} P^{\theta} C\left[H_{D} N_{D}\left(A_{D L}\right)^{\theta-1}\left(\mu \widetilde{R}_{D}-\left(1-d_{D}\right)\right)-M d_{D}\left(A_{D A}\right)^{\theta-1}\right] \widehat{w}_{t} \\
& +\frac{W}{Z}\left(F_{D}+G_{D}\right)\left[\left(1-N_{D}\right) R_{D}-M\right] \widehat{w}_{t}+ \\
& -(1-\theta) \alpha\left(\mu \widetilde{R}_{D}\right)^{-\theta}\left(\frac{W}{Z A_{D H}}\right)^{1-\theta} P^{\theta} C\left[\left(1-N_{D}\right) d_{D} R_{D}\left(A_{D H}\right)^{\theta-1}+M d_{D}\left(A_{D A}\right)^{\theta-1}\right] \widehat{z}_{t} \\
& -(1-\theta) \alpha\left(\mu \widetilde{R}_{D}\right)^{-\theta}\left(\frac{W}{Z A_{D H}}\right)^{1-\theta} P^{\theta} C H_{D} N_{D}\left(A_{D L}\right)^{\theta-1}\left[\mu \widetilde{R}_{D}-\left(1-d_{D}\right)\right] \widehat{z}_{t} \\
& -\frac{W}{Z}\left(F_{D}+G_{D}\right)\left[\left(1-N_{D}\right) R_{D}-M\right] \widehat{z} t \\
& +\alpha\left(\mu \widetilde{R}_{D}\right)^{-\theta}\left(\frac{W}{Z}\right)^{1-\theta} P^{\theta} C\left[-\theta\left[1-N_{D}\right] R_{D} d_{D}\left(A_{D H}\right)^{\theta-1}+\theta M d_{D}\left(A_{D A}\right)^{\theta-1}\right] \widehat{\widetilde{r}}_{D, t} \\
& +\alpha\left(\mu \widetilde{R}_{D}\right)^{-\theta}\left(\frac{W}{Z}\right)^{1-\theta} P^{\theta} C H_{D} N_{D}\left(A_{D L}\right)^{\theta-1}\left[(1-\theta) \mu \widetilde{R}_{D}+\theta\left(1-d_{D}\right)\right] \widehat{\widetilde{r}}_{D, t} \\
& -(1-\theta)\left[1-N_{D}\right] R_{D} d_{D} \alpha\left(\mu \widetilde{R}_{D}\right)^{-\theta}\left(\frac{W}{Z A_{D H}}\right)^{1-\theta} P^{\theta} C \widehat{a}_{D H, t}- \\
& -(1-\theta) H_{D} N_{D} \alpha\left(\mu \widetilde{R}_{D}\right)^{-\theta}\left(\frac{W}{Z A_{D L}}\right)^{1-\theta} P^{\theta} C\left(\mu \widetilde{R}_{D}-\left(1-d_{D}\right)\right) \widehat{a}_{D L, t}+ \\
& +\theta \alpha\left(\mu \widetilde{R}_{D}\right)^{-\theta}\left(\frac{W}{Z}\right)^{1-\theta} P^{\theta} C\left[\left[1-N_{D}\right] R_{D} d_{D}\left(A_{D H}\right)^{\theta-1}-M d_{D}\left(A_{D A}\right)^{\theta-1}\right] \widehat{p}_{t}+ \\
& +\theta \alpha\left(\mu \widetilde{R}_{D}\right)^{-\theta}\left(\frac{W}{Z}\right)^{1-\theta} P^{\theta} C H_{D} N_{D}\left(A_{D L}\right)^{\theta-1}\left[\mu \widetilde{R}_{D}-\left(1-d_{D}\right)\right] \widehat{p}_{t}+ \\
& +\alpha\left(\mu \widetilde{R}_{D}\right)^{-\theta}\left(\frac{W}{Z}\right)^{1-\theta} P^{\theta} C\left[\left[1-N_{D}\right] R_{D} d_{D}\left(A_{D H}\right)^{\theta-1}-M d_{D}\left(A_{D A}\right)^{\theta-1}\right] \widehat{c_{t}} \\
& +\alpha\left(\mu \widetilde{R}_{D}\right)^{-\theta}\left(\frac{W}{Z}\right)^{1-\theta} P^{\theta} C H_{D} N_{D}\left(A_{D L}\right)^{\theta-1}\left[\mu \widetilde{R}_{D}-\left(1-d_{D}\right)\right] \widehat{c_{t}} \\
& =-M\left[d_{D} \alpha\left(\mu \widetilde{R}_{D}\right)^{-\theta}\left(\frac{W}{Z A_{D A}}\right)^{1-\theta} P^{\theta} C+\frac{W}{Z}\left(F_{D}+G_{D}\right)\right] \widehat{b}_{t}
\end{aligned}
$$


Participation constraint - exporters:

$$
\begin{aligned}
& \left(1-N_{E}\right) R_{E}\left[d_{E}(1-\alpha)\left(\mu \widetilde{R}_{E}\right)^{-\theta}\left(\frac{W}{Z A_{E H}}\right)^{1-\theta} P^{\theta} C+\frac{W}{Z}\left(F_{E}+G_{E}\right)\right] \widehat{r}_{E, t}+ \\
& +N_{E}(1-\alpha)\left(\mu \widetilde{R}_{E}\right)^{-\theta}\left(\frac{W}{Z}\right)^{1-\theta} P^{\theta} C\left(H_{E}\left(A_{E L}\right)^{\theta-1}\left(\mu \widetilde{R}_{E}-\left(1-d_{E}\right)\right)-R_{E} d_{E}\left(A_{E L}\right)^{\theta-1}\right) \widehat{n}_{E, t}+ \\
& -N_{E} R_{E} \frac{W}{Z}\left(F_{E}+G_{E}\right) \widehat{n}_{E, t}+ \\
& +(1-\theta)(1-\alpha)\left(\mu \widetilde{R}_{E}\right)^{-\theta}\left(\frac{W}{Z}\right)^{1-\theta} P^{\theta} C\left[\left[1-N_{E}\right] R_{E} d_{E}\left(A_{E H}\right)^{\theta-1}-M d_{E}\left(A_{E A}\right)^{\theta-1}\right] \widehat{w}_{t} \\
& +(1-\theta)(1-\alpha)\left(\mu \widetilde{R}_{E}\right)^{-\theta}\left(\frac{W}{Z}\right)^{1-\theta} P^{\theta} C\left[H_{E} N_{E}\left(A_{E L}\right)^{\theta-1}\left(\mu \widetilde{R}_{E}-\left(1-d_{E}\right)\right)\right] \widehat{w}_{t} \\
& +\frac{W}{Z}\left(F_{E}+G_{E}\right)\left[\left(1-N_{E}\right) R_{E}-M\right] \widehat{w}_{t} \\
& -(1-\theta)(1-\alpha)\left(\mu \widetilde{R}_{E}\right)^{-\theta}\left(\frac{W}{Z}\right)^{1-\theta} P^{\theta} C\left(\left[1-N_{E}\right] d_{E} R_{E}\left(A_{E H}\right)^{\theta-1}-M d_{E}\left(A_{E A}\right)^{\theta-1}\right) \widehat{z}_{t} \\
& -(1-\theta)(1-\alpha)\left(\mu \widetilde{R}_{E}\right)^{-\theta}\left(\frac{W}{Z}\right)^{1-\theta} P^{\theta} C\left(H_{E} N_{E}\left(A_{E L}\right)^{\theta-1}\left[\mu \widetilde{R}_{E}-\left(1-d_{E}\right)\right]\right) \widehat{z}_{t} \\
& -\frac{W}{Z}\left(F_{E}+G_{E}\right)\left[\left(1-N_{E}\right) R_{E}-M\right] \widehat{z}_{t} \\
& -(1-\alpha)\left(\mu \widetilde{R}_{E}\right)^{-\theta}\left(\frac{W}{Z}\right)^{1-\theta} P^{\theta} C\left[\theta\left[1-N_{E}\right] R_{E} d_{E}\left(A_{E H}\right)^{\theta-1}-\theta M d_{E}\left(A_{E A}\right)^{\theta-1}\right] \widehat{\widetilde{r}}_{E, t} \\
& +(1-\alpha)\left(\mu \widetilde{R}_{E}\right)^{-\theta}\left(\frac{W}{Z}\right)^{1-\theta} P^{\theta} C\left[H_{E} N_{E}^{\theta-1}\left(A_{E L}\right)^{\theta-1}\left[(1-\theta) \mu \widetilde{R}_{E}+\theta\left(1-d_{E}\right)\right]\right] \widehat{\widetilde{r}}_{E, t} \\
& -(1-\theta)\left[1-N_{E}\right] R_{E} d_{E}(1-\alpha)\left(\mu \widetilde{R}_{E}\right)^{-\theta}\left(\frac{W}{Z A_{E H}}\right)^{1-\theta} P^{\theta} C \widehat{a}_{E H, t} \\
& -(1-\theta) H_{E} N_{E}(1-\alpha)\left(\mu \widetilde{R}_{E}\right)^{-\theta}\left(\frac{W}{Z_{t} A_{E L}}\right)^{1-\theta} P^{\theta} C\left(\mu \widetilde{R}_{E}-\left(1-d_{D}\right)\right) \widehat{a}_{E L, t} \\
& +\theta(1-\alpha)\left(\mu \widetilde{R}_{E}\right)^{-\theta}\left(\frac{W}{Z}\right)^{1-\theta} P^{\theta} C\left[\left[1-N_{E}\right] R_{E} d_{E}\left(A_{E H}\right)^{\theta-1}-M d_{E}\left(A_{E A}\right)^{\theta-1}\right] \widehat{p}_{t} \\
& +\theta(1-\alpha)\left(\mu \widetilde{R}_{E}\right)^{-\theta}\left(\frac{W}{Z}\right)^{1-\theta} P^{\theta} C H_{E} N_{E}\left(A_{E L}\right)^{\theta-1}\left[\mu \widetilde{R}_{E}-\left(1-d_{E}\right)\right] \widehat{p}_{t} \\
& +(1-\alpha)\left(\mu \widetilde{R}_{E}\right)^{-\theta}\left(\frac{W}{Z}\right)^{1-\theta} P^{\theta} C\left[\left[1-N_{E}\right] R_{E} d_{E}\left(A_{E H}\right)^{\theta-1}-M d_{E}\left(A_{E A}\right)^{\theta-1}\right] \widehat{c}_{t} \\
& +(1-\alpha)\left(\mu \widetilde{R}_{E}\right)^{-\theta}\left(\frac{W}{Z}\right)^{1-\theta} P^{\theta} C H_{E} N_{E}\left(A_{E L}\right)^{\theta-1}\left[\mu \widetilde{R}_{E}-\left(1-d_{E}\right)\right] \widehat{c}_{t} \\
& =-M\left[d_{E}(1-\alpha)\left(\mu \widetilde{R}_{E}\right)^{-\theta}\left(\frac{W}{Z A_{E A}}\right)^{1-\theta} P^{\theta} C+\frac{W}{Z}\left(F_{E}+G_{E}\right)\right] \widehat{b}_{t}
\end{aligned}
$$


Productivity shock

$$
\widehat{z}_{t}=\rho_{z} \widehat{z}_{t-1}+\xi_{t}^{z}
$$

Demand shock

$$
\widehat{u}_{t}=\rho_{u} \widehat{u}_{t-1}+\xi_{t}^{u}
$$

Financial shock

$$
\widehat{b}_{t}=\rho_{b} \widehat{b}_{t-1}+\xi_{t}^{b}
$$

The complete model consists of all the above listed equilibrium conditions for the Home economy and the Foreign economy equivalents of the equilibrium conditions: (63)-(88).

\section{A.3 Structural Parameters}

Table 3 Structural parameters

\begin{tabular}{lll}
\hline Parameter & Description & Value \\
\hline$\sigma$ & Inverse of the intertemporal elasticity of substitution in consumption & 2.0 \\
$\varphi$ & Inverse of the Frisch elasticity of labour supply & 2.0 \\
$\theta$ & Elasticity of substitution between any two varieties & 6.0 \\
$\alpha$ & Parameter determining the fraction of domestic goods in consumption & 0.5 \\
$k$ & Pareto distribution shape parameter & 6.25 \\
$F_{D}=F_{E}$ & Fixed firm set-up cost - domestic retailers and exporters & 0.0169 \\
$G_{D}=G_{E}$ & Financial intermediation fee - domestic retailers and exporters & 0.001 \\
$H_{D}=H_{E}$ & Loan recovery cost - domestic retailers and exporters & 0.5 \\
$d_{D}$ & Fraction of working capital financed externally - domestic retailers & 0.5 \\
$d_{E}$ & Fraction of working capital financed externally - exporters & 0.8 \\
$\omega$ & Probability of a bank's death & 0.01 \\
$\rho_{z}$ & Persistence of productivity shocks & 0.7422 \\
$\rho_{u}$ & Persistence of shocks to the marginal utility of consumption & 0.7989 \\
$\rho_{b}$ & Persistence of shocks to the cost of finance for banks & 0.7296 \\
$\sigma_{z}$ & Standard deviation of innovations to productivity & 0.0122 \\
$\sigma_{u}$ & Standard deviation of innovations to the marginal utility of consumption & 0.093 \\
$\sigma_{b}$ & Standard deviation of innovations to the probability of a bank's survival & 0.016 \\
\hline & &
\end{tabular}




\section{A.4 Robustness Analysis}

In order to evaluate the robustness of the results, additional structural shocks were introduced into the model and the empirical fit of the extended model was then tested with Indirect Inference.

Firstly, an additional preference shock in the form of changes in the elasticity of substitution between varieties, $\theta$, was added to the model. It was assumed that $\ln \theta_{t}=\rho_{\theta} \ln \theta_{t-1}+\xi_{t}^{\theta}$ where $\rho_{\theta} \in\langle 0,1)$ and $\xi_{t}^{\theta} \sim N\left(0, \sigma_{\theta}^{2}\right)$. This resulted in a timevarying mark-up, $\mu_{t}$, and introduced an additional structural shock into the price and consumption equations as well as into a number of other log-linearized equilibrium conditions, including the equations determining the threshold productivity levels for domestic retailers and exporters, the average productivity levels of defaulting and non-defaulting firms as well as banks' participation constraints for lending to domestic retailers and exporters. The model's structural shocks to productivity, the marginal utility of consumption, the probability of a bank's survival and the elasticity of substitution between varieties were estimated using detrended quarterly US data for real trade, real wage, the relative price of exported to domestic goods and the loan write-off rate during the time period from 1985 Q1 to 2017 Q4. In the estimation, the model's structural parameters were set at their calibrated values, as described in Section 5, whereby the persistence parameters of the structural shocks were estimated from the data. As in the case of the baseline model, a non-parametric bootstrap with repeated draws by time vector was used to generate 10,000 samples of the innovations over the sample period and to obtain 10,000 samples of model variables. The actual and simulated data were then used to estimate a VAR(1) in real trade, real wages, the relative price of exports and the loan write-off rate. Based on the Wald statistic, calculated on the VAR coefficients and the variances of innovations, the structural model could not be rejected at the $58 \%$ significance level. The results were similar when the structural shocks and the VAR models were estimated using data for real trade, real wages, the relative export price and output. In this case the null hypothesis that the structural model is correct could not be rejected at the $46 \%$ significance level.

The model was then extended to incorporate a number of other structural shocks: shocks to the loan recovery costs (represented by the parameters $H_{D}$ and $H_{E}$ ), shocks to the financial intermediation fee (represented by the parameters $G_{D}$ and $G_{E}$ ) and shocks to the working capital financing needs (represented by the parameters $d_{D}$ and $d_{E}$ ). In all cases, when tested with Indirect Inference following the procedure described above and based on data for real trade, real wages, the relative export price and the loan write-off rate, the null hypothesis that the structural model provides an accurate representation of the data could not be rejected at the $56 \%$ significance level or higher.

\section{A.5 Historical Variance Decomposition}

The figures below show the contribution of each structural shock to the evolution of the key model variables during the sample period. 


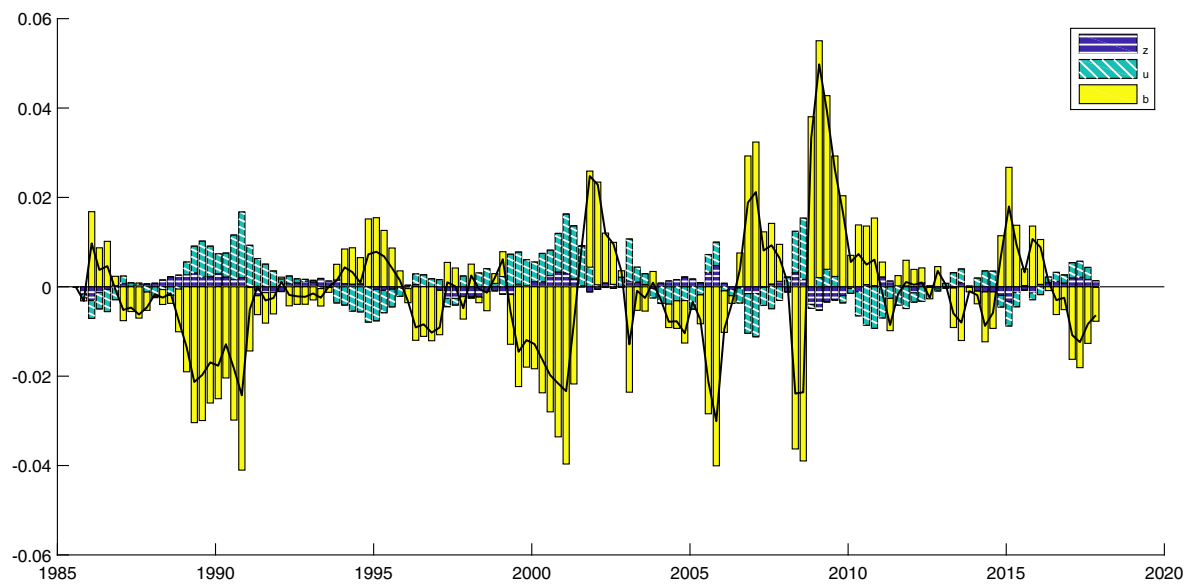

Fig. 13 The contribution of structural shocks to the evolution of the borrowing cost of domestic retailers. Note: the bars represent the impact of the productivity $(z)$, demand $(u)$ and financial $(b)$ shocks on the borrowing cost of domestic retailers, while the solid line represents the combined impact of all the shocks

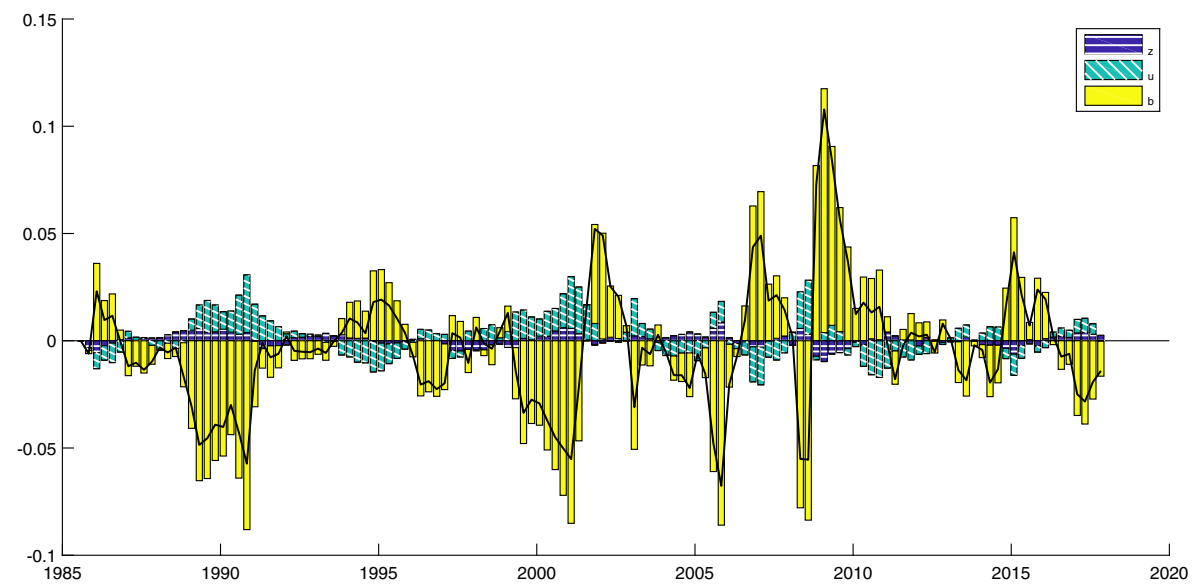

Fig. 14 The contribution of structural shocks to the evolution of the borrowing cost of exporters. Note: the bars represent the impact of the productivity $(z)$, demand $(u)$ and financial $(b)$ shocks on the borrowing cost of exporters, while the solid line represents the combined impact of all the shocks 


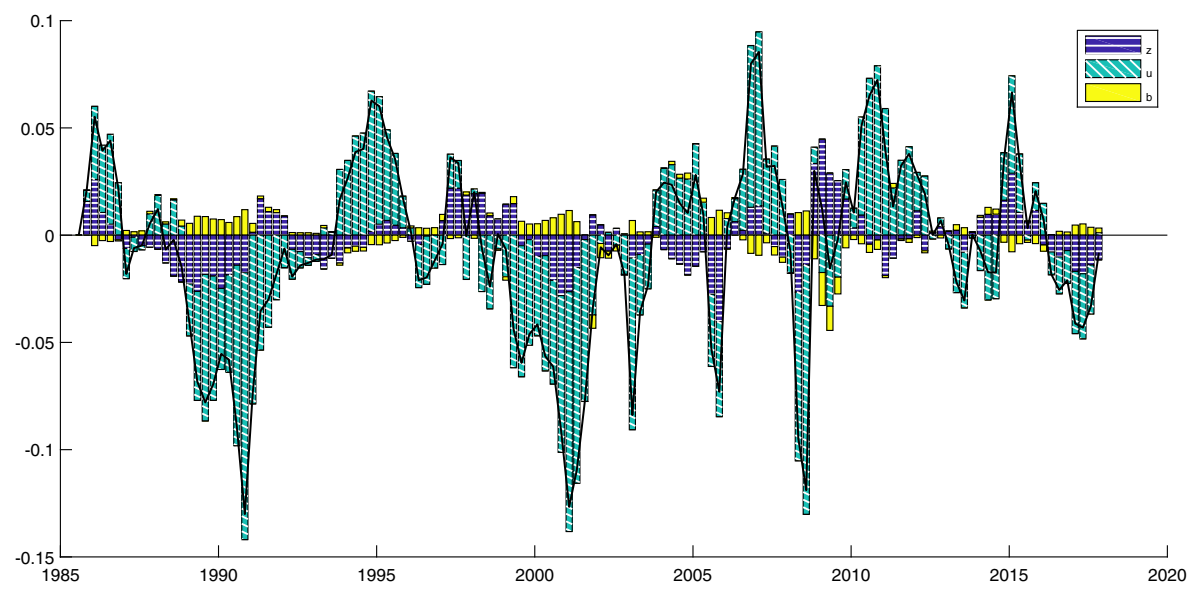

Fig. 15 The contribution of structural shocks to the evolution of output. Note: the bars represent the impact of the productivity $(z)$, demand $(u)$ and financial $(b)$ shocks on output, while the solid line represents the combined impact of all the shocks

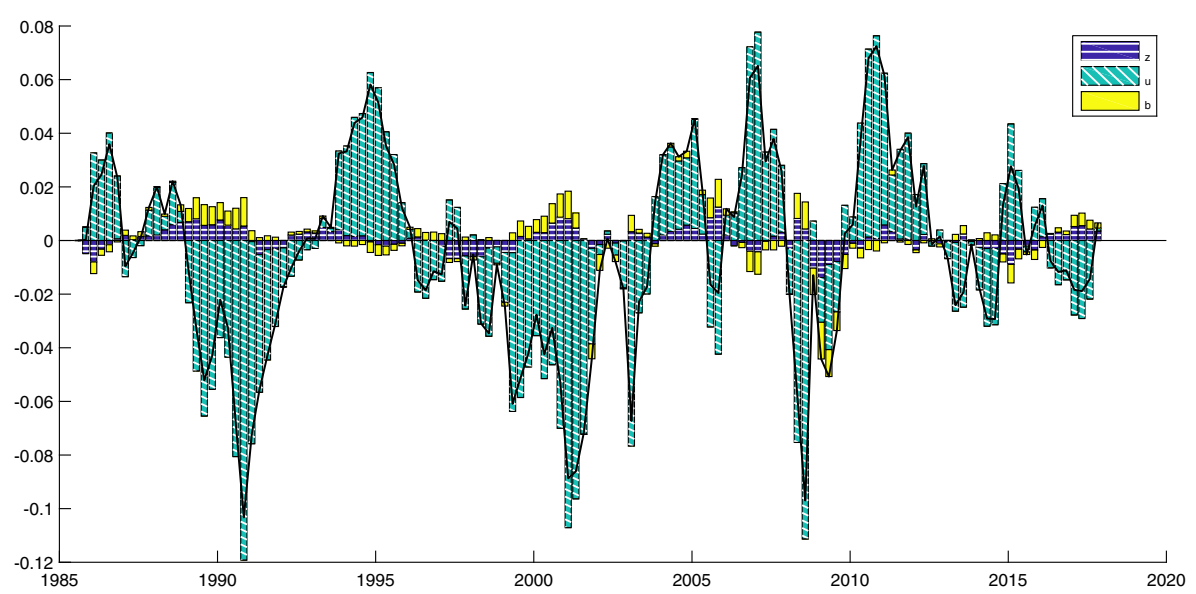

Fig. 16 The contribution of structural shocks to the evolution of labour supply. Note: the bars represent the impact of the productivity $(z)$, demand $(u)$ and financial $(b)$ shocks on labour supply, while the solid line represents the combined impact of all the shocks 


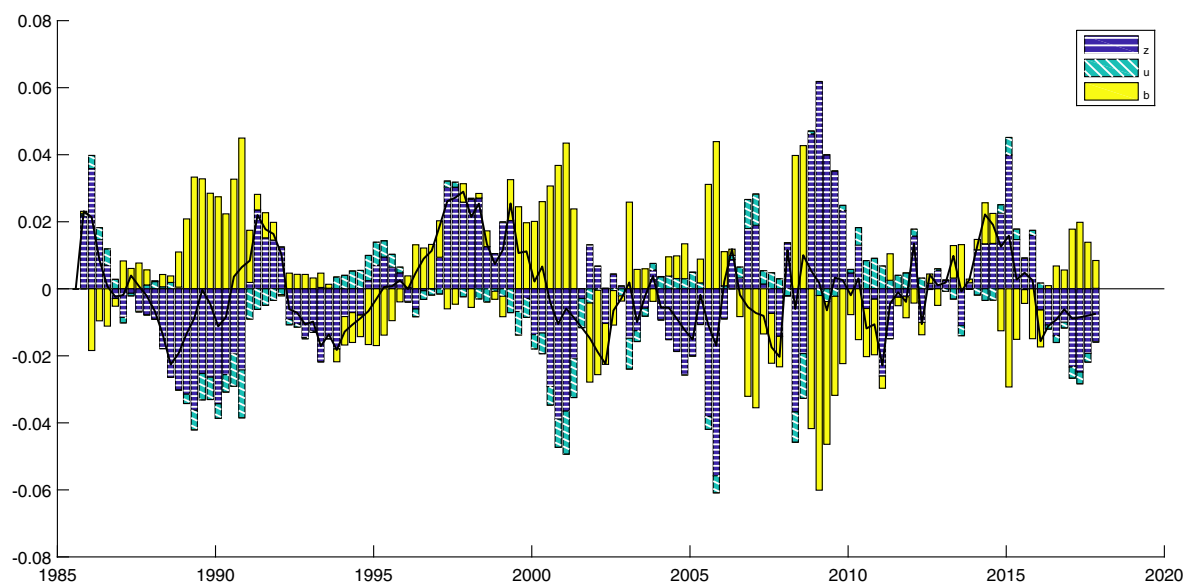

Fig. 17 The contribution of structural shocks to the evolution of wages. Note: the bars represent the impact of the productivity $(z)$, demand $(u)$ and financial $(b)$ shocks on wages, while the solid line represents the combined impact of all the shocks

\section{References}

Ahn J (2011) A theory of domestic and international trade finance. IMF Working Paper No. 11/262

Ahn J, Amiti M, Weinstein D (2011) Trade finance and the great trade collapse. American Economic Review Papers and Proceedings 101(3):298-302

Alessandria G, Kaboski J, Midrigan V (2010) The great trade collapse of 2008-09: an inventory adjustment? IMF Econ Rev 58(2):254-294

Amiti M, Weinstein D (2011) Exports and financial shocks. Q J Econ 126(4):1841-1877

Antràs P, Foley CF (2015) Poultry in motion: a study of international trade finance practices. J Polit Econ 123(4):809-852

Asarnow E, Edwards D (1995) Measuring loss on default bank loans: a 24-year study. J Commer Lend 77(7):11-23

Auboin M (2009) Restoring trade finance during a period of financial crisis: stock-taking of recent initiatives, WTO Staff Working Paper ERSD-2009-16

Axtell R (2001) Zipf distribution of U.S. firm sizes. Science 293(5536):1818-1820

Baldwin R (2009) The great trade collapse: causes, consequences and prospects, VoxEU.org Ebook, available at http://www.voxeu.org/index.php?q=node/4297

Bems R, Johnson R, Yi K (2010) The role of vertical linkages in the propagation of the global downturn of 2008. IMF Econ Rev 58(2):295-326

Berman N, Martin P (2012) The vulnerability of sub-Saharan Africa to the financial crisis: the case of trade. IMF Econ Rev 60(3):329-364

Berman N, de Sousa J, Martin P, Mayer T (2013) Time to ship during financial crises. NBER International Seminar on Macroeconomics 9(1):225-260

Bernanke B, Gertler M, Gilchrist S (1999) The financial accelerator in a quantitative business cycle framework. In: Taylor JB, Woodford M (eds) Handbook of macroeconomics, vol 1c. North Holland, Amsterdam and Kidlington, pp 1341-1393

Blundell R, MaCurdy T (1999) Labor supply: a review of alternative approaches. In: Orley C, Ashenfelter D (eds) Handbook of labor economics, vol 3a. North Holland, Amsterdam and Kidlington, pp 15591695

Braun M, Larrain B (2005) Finance and the business cycle: international, inter-industry evidence. J Financ $60(3): 1097-1128$ 
Bricongne J, Fontagné L, Gaulier G, Taglioni D, Vicard V (2012) Firms and the global crisis: French exports in the turmoil. J Int Econ 81(1):134-146

Bussière M, Callegari G, Ghironi F, Sestieri G, Yamano N (2013) Estimating trade elasticities: demand composition and the trade collapse of 2008-09. Am Econ J Macroecon 5(3):118-151

Calabrese R, Zenga M (2010) Bank loan recovery rates: measuring and nonparametric density estimation. J Bank Financ 34(5):903-911

Carlstrom C, Fuerst T (1998) Agency costs and business cycles. Econ Theory 12(3):583-597

Caselli S, Gatti S, Querci F (2008) The sensitivity of the loss given default rate to systematic risk: new empirical evidence on bank loans. J Financ Serv Res 34(1):1-34

Castro R, Clementi G, Lee Y (2015) Cross-sectoral variation in the volatility of plant-level idiosyncratic shocks. J Ind Econ 63(1):1-29

Chaney T (2016) Liquidity constrained exporters. J Econ Dyn Control 72(C):141-154

Chari V, Kehoe P, McGrattan E (2007) Business cycle accounting. Econometrica 75(3):781-836

Chor D, Manova K (2012) Off the cliff and back: credit conditions and international trade during the global financial crisis. J Int Econ 87(1):117-133

Christiano L (1988) Why does inventory investment fluctuate so much? J Monet Econ 21(2-3):247-280

Christiano L, Eichenbaum M, Evans C (2005) Nominal rigidities and the dynamic effects of a shock to monetary policy. J Polit Econ 113(1):1-45

Dell'Ariccia G, Detragiache E, Rajan R (2008) The real effect of banking crises. J Financ Intermed 17(1):89-112

Djankov S, Freund C, Pham C (2010) Trading on time. Rev Econ Stat 92(1):166-173

Dúllmann K, Trapp M (2004) Systematic risk in recovery rates-an empirical analysis of us corporate credit exposures. Deutsche Bundesbank Discussion Paper No. 02/2004

Eaton J, Kortum S, Neimann B, Romalis J (2016) Trade and the global recession. Am Econ Rev 106(11):3401-38

Eck K, Engemann M, Schnitzer M (2014) How trade credits foster exporting. Rev World Econ 151(1):73101

Engel C, Wang J (2011) International trade in durable goods: understanding volatility, cyclicality and elasticities. J Int Econ 83(1):37-52

Erceg C, Guerrieri L, Gust C (2008) Trade adjustment and the composition of trade. J Econ Dyn Control 32(8):2622-2650

Feenstra R, Li Z, Yu M (2014) Exports and credit constraints under incomplete information: theory and evidence from China. Rev Econ Stat 96(4):729-744

Freund C (2009) The trade response to global downturns: historical evidence. World Bank Policy Research Working Paper No. 5015

Fuerst T (1995) Monetary and financial interactions in the business cycle. J Money Credit Bank 27(4):1321-1338

Ghironi F, Melitz M (2005) International trade and macroeconomic dynamics with heterogeneous firms. Q J Econ 120(3):865-915

Giacomini R (2013) The relationship between VAR and DSGE models. In: Fomby TB, Kilian L, Murphy A (eds) VAR models in macroeconomics-new developments and applications: essays in honor of Christopher A. Sims, Advances in Econometrics, vol 32, pp 1-25

Haddad M, Harrison A, Hausman C (2010) Decomposing the great trade collapse: products, prices, and quantities in the 2008-2009 crisis. NBER Working Paper No. 16253

Hall R (1997) Macroeconomic fluctuations and the allocation of time. J Labor Econ 15(1):223-250

Hummels D (2001) Time as a trade barrier. Purdue University GTAP Working Paper No. 1152

Hummels D, Schaur G (2013) Time as a trade barrier. Am Econ Rev 103(7):2935-59

Iacovone L, Zavacka V (2009) Banking crises and exports: lessons from the past. World Bank Working Paper No. 5016

Irwin D (2002) Long-run trends in world trade and income. World Trade Rev 1(1):89-100

Kiyotaki N, Moore J (1997) Credit cycles. J Polit Econ 105(2):211-248

Kobayashi K (2011) A model of financial crises: coordination failure due to bad assets, RIETI Discussion Paper Series 11-E-010

Kwack S, Ahn C, Lee Y, Yang D (2007) Consistent estimates of world trade elasticities and an application to the effects of Chinese Yuan (RMB) appreciation. J Asian Econ 18(2):314-330

Kroszner R, Laeven L, Klingebiel D (2007) Banking crises, financial dependence and growth. J Financ Econ 84(1):187-228 
Le V, Meenagh D, Minford P, Wickens M (2011) How much nominal rigidity is there in the US economy? Testing a new Keynesian DSGE model using indirect inference. J Econ Dyn Control 35:2078-2104

Le V, Meenagh D, Minford P, Wickens M, Xu Y (2016) Testing macro models by indirect inference: a survey for users. Open Econ Rev 27(1):1-38

Levchenko A, Lewis L, Tesar L (2010) The collapse of international trade during the 2008-2009 crisis: in search of the smoking gun. IMF Econ Rev 58(2):214-253

Manova K (2013) Credit constraints, heterogeneous firms, and international trade. Rev Econ Stud 80(2):711-744

Martins J, Scarpetta S, Pilat D (1996) Mark-up ratios in manufacturing industries: estimates for 14 OECD countries. OECD Economics Department Working Papers No. 162

Melitz M (2003) The impact of trade on intra-industry reallocations and aggregate industry productivity. Econometrica 71(6):1695-1725

Minford P, Wickens M, Xu Y (2016) Comparing different data descriptors in indirect inference tests on DSGE models. Econ Lett 145:157-161

Paravisini D, Rappoport V, Schnabl P, Wolfenzon D (2015) Dissecting the effect of credit supply on trade: evidence from matched credit-export data. Rev Econ Stud 82(1):333-359

Pescatori A, Tasci M (2011) Search frictions and the labor wedge, IMF Working Paper No. WP/11/117

Raddatz C (2006) Liquidity needs and vulnerability to financial underdevelopment. J Financ Econ 80(3):677-722

Safavian M, Wimpey J (2007) When do enterprises prefer informal credit? World Bank Policy Research Working Paper No. 4435

Schmidt-Eisenlohr T (2013) Towards a theory of trade finance. J Int Econ 91(1):96-112

Shimer R (2009) Convergence in macroeconomics: the labor wedge. Am Econ J Macroecon 1(1):280-297

Thorburn K (2000) Bankruptcy auctions: costs, debt recovery and firmsurvival. J Financ Econ 58(3):337368

Zhang Z (2009) Recovery rates and macroeconomic conditions: the role of loan covenants. AFA 2010 Atlanta Meetings Paper 